Published in final edited form as:

Wiley Interdiscip Rev Dev Biol. 2012 ; 1(3): 345-369. doi:10.1002/wdev.23.

\title{
DEVELOPMENTAL DIVERSITY OF AMPHIBIANS
}

\author{
Richard P. Elinson and \\ Department of Biological Sciences, Duquesne University, 600 Forbes Avenue, Pittsburgh, PA \\ 15282.elinson@duq.edu
}

Eugenia M. del Pino

Escuela de Ciencias Biológicas, Pontificia Universidad Católica del Ecuador, Avenida 12 de

Octubre 1076 y Roca, Quito, Ecuador

\begin{abstract}
The current model amphibian, Xenopus laevis, develops rapidly in water to a tadpole which metamorphoses into a frog. Many amphibians deviate from the $X$. laevis developmental pattern. Among other adaptations, their embryos develop in foam nests on land or in pouches on their mother's back or on a leaf guarded by a parent. The diversity of developmental patterns includes multinucleated oogenesis, lack of RNA localization, huge non-pigmented eggs, and asynchronous, irregular early cleavages. Variations in patterns of gastrulation highlight the modularity of this critical developmental period. Many species have eliminated the larva or tadpole and directly develop to the adult. The wealth of developmental diversity among amphibians coupled with the wealth of mechanistic information from $X$. laevis permit comparisons that provide deeper insights into developmental processes.
\end{abstract}

\section{Introduction}

Amphibians have long been model organisms for developmental biology. While Xenopus laevis is presently the amphibian model, others had previously enjoyed the spotlight. ${ }^{1-3}$ Various salamanders were used in classic studies by Spemann, Vogt, Harrison, Fankhauser, Holtfreter, and others. ${ }^{4}$ Pleurodeles waltl, the Spanish ribbed newt, was popular in French laboratories, as was Cynops pyrrhogaster, the fire bellied newt, in Japanese laboratories. The Mexican axolotl, Ambystoma mexicanum, emerged as the urodele of choice, since it could be easily bred and maintained in laboratory colonies. This permitted identification of a few mutant genes, largely through the pioneering efforts of Humphrey. 5,6 Presently, the axolotl is the urodele targeted for genomic analysis (http://www.ambystoma.org). ${ }^{6}$ Among frogs, several species of Rana were exploited by Pasteels, Ancel \& Vintemberger, the Barths, and Briggs and King among many. Xenopus laevis arose through its use in pregnancy testing, and it was established as a model for development by Nieuwkoop and Fischberg. ${ }^{2}$

Even among this group of model amphibians, there are fundamental differences in development. Fertilization in most anurans, the frogs, is monospermic as in mammals, but fertilization in most urodeles, the newts and salamanders, is polyspermic. ${ }^{7,8}$ Primordial germ cells form via the germ plasm, a cytoplasmic localization in anurans, but via induction in urodeles. ${ }^{9-12}$ The body form changes completely and abruptly at metamorphosis in anurans, but the body form undergoes minimal, gradual changes in urodeles. ${ }^{13}$ Finally urodeles possess remarkable regeneration abilities, not found in anurans. ${ }^{14}$

We expect to find more variation in embryos of amphibians than in embryos of eutherian mammals for two reasons. First, amphibians have had a long phylogenetic history. Even representatives of model systems diverged from each other hundreds of millions of years ago. Second, all of the amphibians used as models are similar in that early development 
takes place in water. There are a large number of amphibian species whose embryos develop either on land or in the body of the adult. ${ }^{15,16}$ In the evolution of these species, the embryos had to adapt to new environments, quite different from pond water. In contrast, development of eutherian mammals occurs in the conserved environment of the amnion within the uterus. We will review aspects of reproduction and embryonic development in amphibians that develop in a variety of environments.

\section{PHYLOGENY}

There are three amphibian orders, the anurans, the urodeles, and the legless caecilians, which are part of the monophyletic Lissamphibians. While the urodeles and anurans are considered to be more closely related to each other than either is to caecilians, the last common ancestors were in the Permian, 300-250 million years ago (MYA). ${ }^{17}$ By comparison, the last common ancestor of mouse and human lived about $100 \mathrm{MYA}$ (http:// timetree.org).

Within anurans, commonly used frogs of the genera Gastrotheca, Eleutherodactylus, Bufo, and Rana are part of the monophyletic clade Neobatrachia. ${ }^{18}$ Species of Gastrotheca, Eleutherodactylus, and Bufo shared common ancestors about $55 \mathrm{MYA}$, and the last common ancestor between this group and Rana was present 160 MYA. Xenopus, which belongs to a different clade, shared a common ancestor with the Neobatrachia about 230 MYA.

The long evolutionary times between amphibian clades is coupled with the diversity of environments for development of amphibian embryos. These two features require us to examine amphibians other than the model ones in order to understand alternative developmental paths.

\section{DEVELOPMENTAL ADAPTATIONS IN CAECILIANS}

Caecilians include 188 species (http://amphibiaweb.org, 2011), distributed in tropical regions of the world. ${ }^{15}$ These elongate and limbless amphibians have secluded life habits, a feature that limits study of their embryos, and consequently embryonic development is little known in this group. ${ }^{19}$ Their reproductive modes include oviparity with free-living larvae, direct development, and viviparity. Developmental tables for a few caecilians are available. 19,20

The independent origin of the elongated, limbless body plan in caecilians and reptiles provides opportunities to examine the developmental evolution of this morphology. Woltering et al ${ }^{21}$ recently used embryos of the caecilian Icthyophis to compare their elongated morphology to that of snakes. Of the 126 vertebrae, 120 are rib-bearing thoracic types. Within the somites that give rise to these thoracic vertebrae however, there are transitions in Hox gene expression which in other animals are associated with transitions in vertebral type. The contrast between the presence of Hox transitions and the absence of vertebral transitions in a caecilian and a snake implies that evolution of the elongated body plan involved alternative interpretations of the Hox code. With respect to limblessness, correlations have been made with changes in caecilian Hox gene and cluster structure 22, 23 , but causal connections have not emerged.

There are several feeding strategies among caecilian larvae. ${ }^{24}$ Feeding by suction occurs in larvae of oviparous caecilians in aquatic habitats, and scraping of the uterine epithelium is the mode of prenatal feeding in viviparous species. Juveniles of two direct developing oviparous species feed on the skin of their mothers. ${ }^{25,26}$ Feeding switches to prey capture by biting in adult caecilians. The various feeding modes of oviparous and viviparous caecilians are in turn correlated with differences in jaw development. ${ }^{24}$ Further 
investigations of caecilian early development will undoubtedly reveal more unexpected characters.

\section{DEVELOPMENTAL ADAPTATIONS IN URODELES}

Development of aquatic larvae and metamorphosis to terrestrial adults is typical of urodeles in the genera Triturus, Taricha, Notophthalmus, Pleurodeles, Cynops, and Ambystoma. This reproductive mode is not predominant however among urodeles, as $68 \%$ of all urodele species are lungless salamanders of the family Plethodontidae and have direct development. 13,27

\section{Aquatic development in urodeles and paedomorphosis}

In contrast to caecilians, urodeles are classical organisms for developmental investigations. In fact, research on early amphibian embryos was concentrated on urodele species with a shift towards anurans, particularly $X$. laevis, only in the last half century. ${ }^{28}$ Eggs of urodeles are larger than those of $X$. laevis, and the embryos develop slower, features which facilitate experimental manipulations such as grafting. Anyone studying neural development in $X$. laevis would look enviously at the prominent neural folds in a urodele embryo.

The most widely used urodele, $A$. mexicanum, exhibits the unusual life history of paedomorphosis, in which the aquatic larval form persists, and the axolotl becomes reproductive without metamorphosing. The failure to metamorphose is a derived condition of insufficient thyroid hormone; addition of thyroid hormone causes transformation to the terrestrial adult. ${ }^{29-31}$ Natural populations of some Ambystomid species exhibit facultative paedomorphosis, and the frequency of paedomorphosis vs. metamorphosis is influenced by environmental factors. ${ }^{32,33}$ It is possible to cross paedomorphic and metamorphic species. These crosses indicate that metamorphosis is dominant to paedomorphosis and that there are several genetic bases for paedomorphosis. ${ }^{34}$ Given the plasticity in the genus, it is of interest that metamorphosis was apparently more frequent in the original axolotls, brought to Europe in the nineteenth century. ${ }^{35}$ This suggests that paedomorphosis was selected for in laboratory colonies.

Paedomorphosis arose independently several times among urodeles ${ }^{15}$, so it might be expected that the underlying molecular mechanisms differ among paedomorphic species. Indeed unlike $A$. mexicanum, the mudpuppy, Necturus maculosus, does not undergo metamorphosis in response to exogenous thyroid hormone. Surprisingly, thyroid hormone receptors are functional and expressed in $N$. maculosus 36,37 , raising the hypothesis that key regulatory genes, downstream of receptor activity have been altered to yield paedomorphosis.

In contrast to the numerous origins in urodeles, paedomorphosis has never been found in anurans. Wassersug ${ }^{38}$ argued that the unusual morphology of the anuran larva, the tadpole, precludes attaining the ability to reproduce. Nonetheless, ovaries with growing oocytes and testes with sperm occurred in giant $X$. laevis tadpoles, which lacked thyroid glands and failed to metamorphose. ${ }^{39}$

\section{Development in plethodontid salamanders}

While reproduction as a larva in paedogenesis is one extreme, the other extreme is direct development in which the larva is eliminated, as found among the speciose plethodontid salamanders. Far less is known about development of plethodontids than of urodeles with aquatic reproduction. Plethodontids deposit large eggs with abundant yolk on land. Large egg size is associated with slow developmental rate and modifications of cleavage pattern, blastocoel roof thickness, and gastrulation. ${ }^{40,41}$ Collazo and Keller ${ }^{41}$ document these 
changes in Ensatina eschscholtzii with a $6 \mathrm{~mm}$ egg. These embryos appear to form an embryonic disk, which until now has only been described for the anuran Gastrotheca riobambae. ${ }^{42}$ Plethodontids are distributed in the Americas and southern Europe. ${ }^{15}$ Direct development is considered to underlie their evolutionary success. ${ }^{40,43}$

\section{DEVELOPMENTAL ADAPTATIONS IN FROGS}

Anurans include 5,999 species (http://amphibiaweb.org, 2011) with great diversity of reproductive modes. ${ }^{15}$ The most familiar reproductive mode includes the aquatic larval tadpole, which eats and grows until it metamorphoses into a terrestrial adult frog. Not all tadpoles live in water, however. Some begin development on land in foam nests; others are carried by a parent or incubated in the parent's body. Some do not feed and live off the yolk in the egg. In the extreme cases, tadpoles have been deleted from the life histories, and froglets develop directly from the egg. We will first review several features of tadpoles.

\section{The tadpole's unusual morphology}

The body plans of larval anurans, the tadpoles, look very different from adults and from any other vertebrate. Although tadpoles are aquatic, they do not look like fish. Tadpoles have a bulbous head and body, no neck, and a muscular tail lacking vertebrae. Other tadpole oddities are keratinous teeth which are not derived from neural crest, extra jaw cartilages to support this mouth designed for scraping plant material, and an elongated gut without a stomach. While there are species-specific differences between tadpoles ${ }^{15}, 44$, the shared derived characters unite tadpoles in a monophyletic grouping. In other words, there was one origin of the tadpole morphology in some ancestral anuran, and all anurans are derived from that ancestor.

The body plan of the tadpole can be compared to the body plan of the urodele larva. Larval and adult urodeles look similar. Both have elongated bodies with long tails and four legs, splayed out to the side. Vertebrae continue into the tail. The vertebral column moves horizontally in a sinusoidal motion during locomotion, when either swimming or walking. Metamorphosis in urodeles affects skin, gills, tail fins, and other structures, but the form of the body remains the same.

The evolutionary origin of the odd tadpole morphology is likely related to the existence of thyroid dependent metamorphosis. If we start from the urodele condition, any modification can be made to the larva as long as that structure is destroyed at metamorphosis. For example, tadpoles have a long intestine, useful for extracting nutrients from plants and detritus. At metamorphosis, the intestine shrinks by $75 \%$ and is remodeled to produce a gut suitable for adult carnivory. The specialized keratinous teeth and beak and the extra jaw cartilages, all designed for feeding by scraping a substrate, are destroyed at metamorphosis as are the muscles and notochord of the tail.

Tail cartilage - Two variations in tadpole developmental characters have recently been investigated, namely tail cartilage and carnivory. Tail vertebral cartilages are present in tadpoles of the family Megophyridae. ${ }^{45-47}$ Other species can develop cartilages in the form of pelvic elements and hind limbs from amputated tails, regenerating in the presence of retinoic acid. ${ }^{48,49}$ The cartilages in the tail of megophyrids or in the regeneration paradigm could arise either from sclerotome, which is normally inactive, or from a transdetermination of another cell type to cartilage. A preliminary report of expression of pax 1, a sclerotome marker, in tails of $X$. laevis embryos, suggests that the sclerotome begins development in tadpole tails, but then arrests. 50 
Mouth and digestive tract-Although most tadpoles eat plant material and detritus, there are carnivorous forms. These require modifications of the jaw, including more massive musculature, and a fundamentally different kind of digestive tract. Carnivorous forms have shorter intestines and a true stomach. Tadpoles of Lepidobatrachus laevis are obligate carnivores and continue eating through metamorphosis. ${ }^{51,52}$ In addition to obligate carnivores, there are species whose tadpoles can switch from omnivores to carnivores with corresponding morphological modifications. This polyphenism has been best documented for two species of spadefoot toad which convert to carnivores when the density of shrimp for food is high. ${ }^{53-58}$ The keratinous teeth are reduced but the keratinous beak thickens. Jaw muscles enlarge, and the gut shortens.

There is a parallel polyphenism in urodeles called cannibalistic morphs. Among the North American tiger salamander, Ambystoma tigrinum, and the Japanese salamander, Hynobius retardus, larvae arise with enlarged, broad heads and a greater number of larger vomerine teeth. ${ }^{59-61}$ The presence of cannibalistic morphs is due to environmental factors, including the type of prey available $61-63$, water currents ${ }^{64}$, and egg size. ${ }^{65}$

Besides carnivorous tadpoles, there are tadpoles that do not eat, called nidicolous endotrophs. ${ }^{16,66,67}$ The yolk in the egg is sufficient for them to metamorphose. An intermediate between feeding and non-feeding tadpoles is a facultative feeder. The most famous example is Bufo periglenes, the Costa Rican golden toad ${ }^{68}$, which is the poster child for disappearing amphibians. Their tadpoles ate when food was available, but they were able to metamorphose without eating. The endotrophic tadpoles, using only the maternal yolk for nutrition, are intermediates to direct developers, which have eliminated the tadpole.

We will next discuss particular terrestrial reproductive modes of frogs whose embryos have been investigated recently.

\section{Foam-nests in túngara frogs}

The genus Engystomops includes 9 species (http://amphibiaweb.org, 2011), distributed in Central and South America. ${ }^{69}$ Sexual selection, behavior, and ecology have been studied in Engystomops (formerly Physalaemus) pustulosus. ${ }^{69-71}$ Development was analyzed in E. pustulosus, E. coloradorum, and E. randi.

Engystomops pustulosus reproduces in temporal pools of water, and during amplexus, the egg jelly is beaten into white foam by the male. The major component of the foam is ranaspumin-2, a surfactant protein compatible with developing embryos. ${ }^{72}$ The foam-nest floats, has antimicrobial properties, reflects solar radiation, and camouflages eggs and embryos. ${ }^{70-74}$ By means of the foam-nest, developing eggs are removed from the aquatic environment, and protected from desiccation and predators. After about two days, tadpoles fall into the water. Methods for túngara frog maintenance and embryo manipulation are given in Romero-Carvajal et al. ${ }^{75}$

Engystomops pustulosus has synchronous and asynchronous phases of oogenesis, a feature that has been experimentally exploited. ${ }^{73}$ Oocytes contain lampbrush chromosomes, and the pattern of new RNA synthesis in embryos resembles that of other anurans. ${ }^{73}$ Maternal transcripts are retained in embryos to the tadpole stage as in X. laevis. ${ }^{76}$

Early embryos resemble $X$. laevis albino embryos in size, developmental speed, and appearance until the neurula stage. The neural plate, neural folds, and streams of cranial neural crest cells are larger than in $X$. laevis. Somitogenesis involves small cells and cell intercalation, as found in Bombina variegata, G. riobambae, Epipedobates (formerly 
Colostethus) machalilla, and other dendrobatid frogs..$^{75,77-79}$ In contrast, somitogenesis in $X$. laevis involves rotation of fewer, large cells that span the somite length. ${ }^{77,80}$ A table of developmental stages is given in Romero-Carvajal et al. ${ }^{75}$ Pigment granule development and gastrulation are discussed in a later section.

The yolk is incorporated into the gut during early development in embryos of $X$. laevis and other small amphibian eggs. ${ }^{81,82}$ Túngara frogs are an exception, as yolky cells bulge into a yolk sac at the tail bud stage in spite of the small size of eggs. Tail bud embryos of túngara and dendrobatid frogs and of G. riobambae (Figure 1) resemble amphibian embryos with large telolecithal eggs. ${ }^{15,75,81,83-85}$ The mass of yolky cells resembles nutritional endoderm of $E$. coqui, reviewed later.

\section{Terrestrial nests of dendrobatid frogs}

Dendrobatid frogs include 282 species, distributed in Central and South America (http:// amphibiaweb.org, 2011). ${ }^{15}$ Many dendrobatids are brightly colored and about one third of the species are poisonous. ${ }^{86}$ Skin toxins are derived from the diet and are chemically known. ${ }^{87-89}$ Other species are non-poisonous and darkly colored, such as E. machalilla. 86,90 Methods for frog maintenance and handling of embryos are given in del Pino et al. ${ }^{85}$

Dendrobatid frogs exhibit parental care, and the adult releases the contents of its bladder to moisten the embryos. At hatching, tadpoles attach to the dorsum of the parent in charge and are transported to water, where development advances to metamorphosis. ${ }^{15}$ Eggs have a darkly pigmented animal pole and range in size from $1.6 \mathrm{~mm}$ in diameter in E. machalilla to $3.5 \mathrm{~mm}$ in diameter in other species. ${ }^{79}$ Nests of E. machalilla contain 15 eggs on average, and terrestrial development lasts about 20 days. ${ }^{85}$ Early development until neurula resembles that of $X$. laevis. Thereafter, development follows the large telolecithal egg pattern, described earlier. A table of developmental stages is given in del Pino et al. ${ }^{85}$ Dendrobatid gastrulation is analyzed in a later section.

\section{Egg-brooding in hemiphractid frogs}

Hemiphractid frogs are characterized by brooding of eggs on the female's back and by the membranous external gills of the embryos, named bell gills (Figure 1f). These frogs occur in Central and South America. ${ }^{15}$ Eggs are exposed on the mother's back in Cryptobatrachus, Hemiphractus and Stefania, but they are enclosed inside a dorsal pouch in Flectonotus and Gastrotheca (Figure 2). Because of this pouch, these latter frogs are known as marsupial frogs. ${ }^{15,91}$ Gastrotheca includes 60 of the 95 species of hemiphractid frogs (http:// amphibiaweb.org, 2011).

Only Flectonotus, Fritziana, and a few species of Gastrotheca give birth to tadpoles. Flectonotus tadpoles, however, complete metamorphosis in a few days, without feeding. ${ }^{15,92,93}$ Other hemiphractids are direct-developers. Their embryos develop rudimentary tadpole characters, such as the tail and larval mouth structures. ${ }^{93}$ The tadpole was lost early in the phylogeny of hemiphractids but reappeared within Gastrotheca. ${ }^{91}$ Accordingly, certain tadpole features would have been lost in the evolution of Gastrotheca tadpoles. Larval mouth parts, however, have not been modified. ${ }^{93}$

The pouch of marsupial frogs may derive in evolution from lateral foldings of the dorsal skin that would have enclosed embryos on the female's back. ${ }^{94}$ The pouch anatomy in Flectonotus (Figure 2a, b) and the pouch ontogeny of $G$. riobambae resemble this condition..$^{95,96}$

Pouch development is triggered by gonadotropins, and thereafter, the pouch is a permanent structure of the G. riobambae female. ${ }^{95}$ Progesterone induces the incubatory changes of the 
pouch. Long-lived post-ovulatory follicles may secrete progesterone, allowing embryonic incubation and inhibiting further growth of oocytes during incubation. ${ }^{97,} 98$

The non-incubating pouch structure of Gastrotheca and Flectonotus resembles frog skin. During incubation, the pouch develops vascularized chambers that adhere tightly to each embryo (Figure 2a, c). The fertilization membrane and thin layers of egg jelly separate the pouch from the bell gills of embryos. The nature of exchanges in the pouch is not known. ${ }^{99}$ After birth of tadpoles, the pouch acquires the non-incubatory morphology. Reproductive changes are similar in the pouch of Gastrotheca species that give birth either to tadpoles or froglets. ${ }^{96,100}$ The dorsal skin of the female in Hemiphractus and Stefania, frogs that do not have pouches, form vascularized depressions for each embryo during incubation. ${ }^{96}$ Skin incubation evolved independently in Pipidae. Changes of Pipa dorsal skin for incubation parallels the reproductive changes of pouch morphology in marsupial frogs. ${ }^{101}$

In $G$. riobambae, fertilization is external, and eggs are moved inside the pouch by the male during amplexus. Embryos of $G$. riobambae of 2.5 to $3 \mathrm{~mm}$ in diameter are the smallest among hemiphractids. Cleavage in $G$. riobambae displays modifications associated with large eggs and with slow developmental rate. ${ }^{102}$ Embryos develop from an embryonic disk over the mass of cleaved yolk, and remain flat during the neurula stages, allowing observation of neural and cranial neural crest development (Figure 1). ${ }^{99,103}$ A table of developmental stages was modified to allow comparison of $G$. riobambae gastrulation with $X$. laevis. ${ }^{84,104}$ Oogenesis and gastrulation of hemiphractid frogs are reviewed later.

Incubation in G. riobambae lasts about 4 months. Nitrogen waste excretion was changed to ureotelic in $G$. riobambae embryos and tadpoles. ${ }^{105}$ Ureotelism is an adaptation for prolonged incubation in the maternal pouch of $G$. riobambae and favors development with limited water. ${ }^{105}$ Embryos can be cultured in vitro in a physiological saline solution that contains urea. ${ }^{106}$ At birth, the female aids in the emergence of tadpoles with her feet. ${ }^{99}$ Methods for the maintenance of adults and handling of $G$. riobambae embryos are given in Elinson et al. ${ }^{107}$

\section{Direct development in frogs}

Larvae have been deleted from the life history of all three orders of amphibians, producing the pattern known as direct development. $15,20,27,40,41,43,108-110$ The differences in morphology between the larva and the adult are much greater in frogs than in either urodeles or caecilians, so the appearance of anuran direct developers is particularly striking. ${ }^{16,111-116}$ Although there have been multiple origins of direct developing anurans, their embryos look similar indicating convergent evolution.

The taxon Terrarana is a large group of New World direct developing frogs (900 species in four families). ${ }^{117-119}$ An opportunity to examine the developmental modifications that have occurred for this reproductive mode is provided by Eleutherodactylus coqui (Figure 3).

Mating occurs freely in captivity, and after internal fertilization, eggs are deposited on land. The clutch of embryos is guarded by the male for about three weeks, until the froglets hatch from their jelly capsules. Adults in a laboratory colony remain reproductively active for a year or two, producing clutches of 30 eggs each month. Eleutherodactylus coqui has invaded Hawaii, and the Hawaiians are unsuccessfully trying to get rid of them. As a result, it will be easy to collect adult frogs from Hawaii for the foreseeable future.

Eleutherodactylus coqui, has been used recently to examine development. A staging table was prepared by Townsend and Stewart ${ }^{112}$, and methods for the maintenance of adults and embryos are given in Elinson et al. ${ }^{107}$ The embryos can be cultured in low salt solutions. ${ }^{120}$ Features of E. coqui development are discussed in other sections of this paper. 


\section{MULTINUCLEATED OOGENESIS}

Different organisms, particularly insects, have a variety of mechanisms for making an oocyte. ${ }^{121}$ In insects with panoistic ovaries, there is only one nucleus per oocyte, whereas in the meroistic ovary, oocytes accumulate transcripts and other products derived from oocyte sister cells, the nurse cells. ${ }^{122-125}$ In contrast, a single nucleus provides the required gene products in oocytes of most vertebrates. ${ }^{121}$ Variation of this strategy occurs in frogs with multinucleated oocytes. ${ }^{126}$

\section{Mononucleated oocytes}

Oocytes of frogs and urodeles characteristically have a single large nucleus, known as the germinal vesicle (GV). During diplotene, chromosomes become transcriptionally active and acquire the lampbrush configuration. ${ }^{127}$ Additionally, the GV contains a very large number of nucleoli, Cajal bodies, snurposomes and other structures. ${ }^{128,129}$

Xenopus laevis oocytes accumulate ribosomes that support protein synthesis in the embryo until tadpole stages. Amplification of $r R N A$ genes during pachytene generates thousands of copies of the major $r R N A$ genes that become incorporated into extrachromosomal nucleoli. In contrast to this amplification, the $5 S r R N A$ genes are repeated in the $X$. laevis genome. ${ }^{130}$ Ribosomal gene amplification and the high copy number of $5 S r R N A$ genes contribute to generate the extraordinary number of ribosomes of $X$. laevis oocytes.

\section{8-nucleated oocytes of Ascaphus truei}

The multinucleate condition may derive from a common pattern of incomplete cytokinesis of the last primary oogonia that are thus connected by cytoplasmic bridges, as observed in $X$. laevis and other organisms. ${ }^{131}$ In the tailed frog of North America, Ascaphus truei, there is lack of cytokinesis during the last three oogonial divisions, giving rise to 8-nucleated oocytes. Each nucleus has GV features, with rDNA amplification, nucleoli, lampbrush chromosomes, and RNA synthesis. The level of rDNA amplification of each GV amounts to about $1 / 8$ of the rDNA amplification of $X$. laevis oocytes, and the overall rDNA amplification is comparable with $X$. laevis oocytes. Oocytes remain 8-nucleated until the oocyte measures 2 to $2.5 \mathrm{~mm}$ in diameter, when nuclei degenerate. Only one GV remains in the full grown $A$. truei oocyte. ${ }^{132}$

\section{Oogenesis in hemiphractid frogs}

The mode of oogenesis was screened in 36 species of hemiphractid frogs. In 14 species, oocytes were multinucleated with 4 to about $3000 \mathrm{GVs}$ per oocyte. Oocytes of the 22 remaining species were mononucleated. No particular reproductive difference was detected in hemiphractid frogs with multinucleated oocytes in comparison with those with mononucleated oocytes. ${ }^{99}, 126$

Oocytes of G. riobambae are mononucleated throughout oogenesis, with lampbrush chromosomes, nucleoli, and amplification of $r R N A .{ }^{133}$ The genome contains about 500 copies of one major repeat of $5 S r R N A$ genes, similar to the somatic $5 S r R N A$ gene of $X$. laevis. A limited amplification of ribosomal genes correlates with the low number of $5 S$ $r R N A$ genes in the G. riobambae genome. ${ }^{133}, 134$

Oocytes of $F$. pygmaeus are multinucleated with up to 3000 meiotic nuclei per oocyte (Figure 4). Each GV amplifies the ribosomal genes, and the level of amplification varies among nuclei. The overall amplification of an oocyte with 2500 nuclei is 280 times higher than in X. laevis. ${ }^{135}$ As the F. pygmaeus oocyte grows, peripheral nuclei enlarge and develop lampbrush chromosomes, whereas centrally located nuclei remain small (Figure 4). 
All nuclei are active in RNA synthesis. Oocyte growth is accompanied by nuclear degradation until one final GV remains in full grown oocytes (Figure 4a). ${ }^{126,135}$

The clue to the multinucleated condition most likely relates to acceleration of the process of oogenesis. The single GV of a $X$. laevis oocyte contains only 4 copies of each gene, whereas the genome is repeated 32 times in 8-nucleated oocytes of $A$. truei and 12,000 times in an oocyte of $F$. pygmaeus with $3000 \mathrm{GVs}$. The many nuclei of a multinucleate oocyte may accelerate the accumulation of gene products during oogenesis resembling the function of nurse cells in the meroistic ovary of insects. There are many unsolved questions concerning multinucleated oogenesis. It is unknown whether nuclei of a multinucleated oocyte are derived from the same oogonial cell. The mechanism of nuclear degradation and the features that protect the final GV from degradation are also unknown. The limited access to frogs with this type of oogenesis hampers further investigations.

\section{EGG SIZE}

There is enormous variation in amphibian egg sizes, ranging in diameter from the small Xenopus tropicalis egg with a diameter of $0.7-0.8 \mathrm{~mm}$ to several species of marsupial frogs with egg diameters of 9-10 mm. ${ }^{84,94}$ These extremes represent a difference in egg volume of 1500-3000 times. Anurans that lay their eggs in water and which develop and feed as tadpoles generally have eggs with diameters of 1-2 mm. ${ }^{15}$ Those that begin development out of the water but enter the water as feeding tadpoles usually have eggs that are $2-3 \mathrm{~mm}$ in diameter. Some species of anurans develop directly to frogs with no tadpoles, and the eggs of these direct developers are usually $3-4 \mathrm{~mm}$ in diameter. Urodeles with aquatic development tend to have larger eggs $(2-3 \mathrm{~mm})$ than anurans with aquatic development, and there are even some in the $5-6 \mathrm{~mm}$ range.${ }^{15}$ Particularly among anurans, the larger the egg, the smaller the number of eggs.

While these egg size parameters hold for most species, variations and exceptions abound. For example, a variation in reproductive mode is found in he Surinam toad, Pipa pipa, which is in the South American branch of same family as Xenopus, a representative of the African branch. Although little frogs emerge from capsules on the back of the female, P. pipa is not a direct developer. Tadpoles develop in those capsules from eggs that are 5-6 $\mathrm{mm}$ in diameter. ${ }^{109}$ The egg of the tailed frog, Ascaphus truei, is $4 \mathrm{~mm}$ despite its aquatic, tadpole development. At the other extreme, Sooglossus gardineri is a direct developing frog, but its egg is only $1.8 \mathrm{~mm}$ in diameter. ${ }^{109}$

\section{Egg size and yolk}

Very little is known about how egg size for a species is determined, but it can obviously change with evolution. Much of the variation in egg size is due to increased amounts of yolk, provisioned in the egg for development of the embryo. In the absence of a feeding larva, more yolk is required to generate a terrestrial, carnivorous form that is big enough to capture and eat live prey. Yolk platelets in the oocyte are derived from vitellogenin, synthesized in the liver. Vitellogenin is transported through the blood, and taken up by the growing ovarian oocyte. The oocyte is surrounded by follicle cells, and these can regulate yolk uptake as demonstrated by Wallace and co-workers. Wallace and Misulovin ${ }^{136}$ succeeded in growing $X$. laevis oocytes in vitro in a defined medium, supplemented with vitellogenin. These oocytes, lacking follicle cells, continued to grow in volume linearly beyond the normal size. More remarkably, ovarian oocytes, which were already fully-grown in vivo, resumed growth when placed in vitro. ${ }^{137}$

Beside the role of the follicle cells in regulating yolk uptake and oocyte size, the ploidy of the oocyte can have an effect. Laboratory hybrids between X. laevis and Xenopus gilli ${ }^{138}$ 
and natural hybrids between Lithobates (formerly Rana) lessonae and Lithobates (formerly Rana) ridibunda ${ }^{139-142}$ sometimes lay diploid eggs. Diploid eggs are easy to detect because they are larger than the haploid eggs.

\section{Lack of pigment in large eggs}

Amphibian eggs that give rise to aquatic larva usually have a pigmented animal half, where the nucleus resides, and a non-pigmented, yolkier vegetal half. The animal half can be dark brown or black as with many Rana or Bufo species, or tan as in X. laevis. The vegetal half can be non-pigmented as in Xenopus or Rana, or contain a considerable amount of pigment granules as in some Bufo. Most large eggs, that give rise to non-feeding tadpoles or larvae or directly to adult forms, are unpigmented. The ecological explanation for this difference between aquatic eggs and large eggs is that a dark top and a light bottom provide camouflage in the water. Large eggs are usually brooded in a protected site on land or inside a body cavity of the adult. Like cave animals, pigmentation, that is not needed, would be lost.

Whether or not the ecological explanation is correct, it may be that the processes enriching pigment granules in the animal cortex of the oocyte are linked to yolk uptake, which also involves the cortex. When yolk uptake increases massively, pigment granule production or localization may decrease. Dependence of pigment granule localization on cortical activities is suggested by the recent comparison between $X$. laevis and E. pustulosus. Engystomops pustulosus begins development on land in foam nests. Their small $(1.5 \mathrm{~mm})$ eggs are white, because the pigment granules are accumulated around nuclei of blastomeres. ${ }^{75}$ The localization of pigment granules in the animal cortex of $X$. laevis oocytes depends on shroom2, an actin-binding protein. ${ }^{143}$ Conversely, oocytes of E. pustulosus have little shroom 2 , and both spectrin and pigment granules are concentrated near nuclei in blastulae. It would be interesting to see the distribution of shroom 2 and spectrin in other unpigmented early embryos, particularly those developing from large eggs.

Egg pigmentation is used to identify the prospective dorsal side of the amphibian early embryo. In many species, the gray crescent arises before first cleavage due to the rotation of the egg cortex relative to the cytoplasm. The cortical rotation depends on a transient array of parallel microtubules in the vegetal half. ${ }^{144}$ At the onset of gastrulation, the dorsal lip of the blastopore forms near the juncture of the gray crescent and the non-pigmented vegetal half. A gray crescent is not visible on the lightly pigmented $X$. laevis zygote, but pigment granules accumulate near the site of sperm entry, identifying the prospective ventral side. There is no direct evidence that a cortical rotation, which causes dorsal specification, occurs in large, unpigmented zygotes. The presence of an array of parallel microtubules in E. coqui zygotes, however, suggests that cortical rotation occurs even in very large eggs. ${ }^{145}$

\section{Egg size and cleavage}

Regardless of egg size, eggs of all amphibians undergo holoblastic cleavage, in which the whole egg is divided into small cells. In some large eggs, there appears to be less cleavage of the yolk-rich vegetal region, leading some to call these vegetal divisions pseudomeroblastic or meroblastic. ${ }^{41,146}$ True meroblastic cleavage, as in teleosts, reptiles, and birds, has not been found in amphibians. ${ }^{147,148}$ Cleavage in amphibian eggs, greater than 7 $\mathrm{mm}$ diameter, has not been examined, however.

In most amphibians, cleavage divisions are synchronous until the mid-blastula transition (MBT). Although most intensively investigated in $X$. laevis, the MBT was defined originally in the urodele, $A$. mexicanum. ${ }^{149}$ Each plane of cleavage tends to be perpendicular to the previous plane, yielding stereotypical appearances of morulae at 2-64 cells. A major 
deviation from the standard amphibian pattern occurs in $G$. riobambae, which exhibits both asynchrony and early pattern irregularity. ${ }^{102}$ Nucleoli are present as early as 8 cells, suggesting a lack of an MBT. Cleavage in G. riobambae is very slow, taking about half a day for the first cleavage.

The cleaving $G$. riobambae embryo resembles a mammalian embryo with respect to both slow cleavage and lack of an MBT. ${ }^{102}$ The correlations between slowness, irregularity, and asynchrony of cleavage extend to other amphibians, such as the tailed frog Ascaphus truei. ${ }^{150}$ Cleavage, particularly first cleavage, is much slower in most urodeles compared to most anurans ${ }^{7}$, so asynchronous, irregular cleavage may be more likely among urodeles. Reports on cleavage in several urodeles support this possibility $41,151-153$; however, the relationships between egg size, cleavage timing, and cleavage pattern require fuller analysis.

\section{LOCALIZED RNA}

Early development of the model amphibian $X$. laevis depends on RNAs localized to the vegetal cortex of the oocyte. These RNAs are of two types: germ layer patterners and germ cell determinants. The former include vegt, vg1, and wnt11 RNAs. The latter include nanos 1, dazl, $d d \times 25$, and pat RNAs, which are localized to islands of germ plasm. Based on limited data, some of these RNA localizations are likely basal for anurans. Both vegt and dazlRNAs are localized to the vegetal cortex of the Lithobates (formerly Rana) pipiens oocyte. ${ }^{154}$. In addition, germ plasm has been identified cytologically in various anurans. ${ }^{155}$ Deviations from the $X$. laevis paradigm occur in both the direct developing frog $E$. coqui and the axolotl $A$. mexicanum.

In the large $3.5 \mathrm{~mm}$ oocytes of $E$. coqui, vegt and $v g 1$ RNAs are present diffusely near the animal pole of the oocyte and not at the vegetal cortex. ${ }^{156}$ This distribution correlates with the more animal location of mesoderm in the fate map and the lack of mesoderm inducing activity in most of the vegetal cells of the late blastula and early gastrula (Figure 5). ${ }^{157,158}$ The animal location of vegt and vgl RNAs indicates that the great amount in yolk has altered the oocyte architecture and the subsequent embryonic patterning. There is presently no information of germ plasm, either cytologically or from RNAs of orthologues, for $E$. coqui or for any other anuran with large eggs.

Localization of RNAs to the oocyte vegetal cortex has not been found in A. mexicanum, the only urodele examined in this way. Urodeles lack germ plasm and form primordial germ cells by induction in the ventral marginal zone. ${ }^{9,} 12,159$ Johnson et al ${ }^{12}$ proposed that germ plasm protects primordial germ cells from somatic influences in the early embryo and permits higher levels of evolvability in organisms that use germ plasm. The fact that there are almost ten times more species of anurans than urodeles may be a reflection of this greater evolvability.

Corresponding to the lack of germ plasm, RNA of $A$. mexicanum dazl is present in oocytes but not localized. ${ }^{160,161}$ RNA of the ortholog vegt is also present in oocytes but not localized ${ }^{162}$, indicating that lack of RNA localization extended to a transcription factor which in $X$. laevis determines formation of both endoderm and mesoderm. Based on these few shards of information, there appear to be fundamental differences in the molecular organization of urodele and anuran oocytes.

\section{GASTRULATION, THE ORGANIZER, AND MODULARITY}

The predominant movements of gastrulation in vertebrates are epiboly, internalization, convergence, and extension. ${ }^{163}$ Although these movements are highly conserved, variation 
occurs in amphibians with different reproductive modes. Particularly the timing of dorsal convergence and extension (CE) varies among frogs, as analyzed in this section.

\section{Speed of gastrulation}

The speed of early development varies among frogs. Xenopus laevis and túngara frogs take $14 \mathrm{hrs}$ and $24 \mathrm{hrs}$ respectively to advance from fertilization to the end of gastrulation. ${ }^{75,81}$ In contrast, the dendrobatid frog E. machalilla and the marsupial frog G. riobambae develop more slowly and require 4 and 14 days respectively to complete the same process. ${ }^{42,} 85$ The outlined differences in developmental time may relate to modifications of gastrulation patterns.

\section{LIM homeobox 1 and Brachyury as gastrulation markers}

LIM homeobox 1 (Ihx I) and its expression pattern are conserved in animals. ${ }^{164-168}$ Lhx 1 is implicated in the evolution of the Spemann-Mangold organizer, and its blastoporal expression is conserved from cnidarians to chordates. ${ }^{167}$ In $X$. laevis, IhX 1 induces a secondary axis and acts as transcriptional activator of organizer genes, such as goosecoid, chordin, otx 2, cerberus and paraxial protocadherin. ${ }^{169}$ Lhx 1 has a conserved role in specifying neural identity in flies, nematodes and vertebrates ${ }^{170}$, and it is expressed in intermediate mesoderm, pronephros, and kidney. ${ }^{166,168,171-174}$ Expression of $1 \mathrm{hx} 1$ in gastrula stage embryos of various frogs allowed identification of the dorsal blastopore lip, mesoderm induction, location of the presumptive mesoderm, involution, dorsal mesoderm, including prechordal plate, and notochord, and the separation of endomesoderm from ectodermal cells at Brachet's cleft, in comparison with $I h x 1$ expression in $X$. laevis. $168,171,172,175,176$

Brachyury ( $T$ ) has a conserved role in Bilaterian blastopore formation and gastrulation. ${ }^{177,178} \mathrm{~A}$ regulatory $\mathrm{N}$-terminal domain of brachyury orthologues plays a role in blastopore formation that correlates with brachyury circumblastoporal expression. A subset of brachyury-positive cells acquired mesodermal specification functions during evolution. ${ }^{178}$ Brachyury is an early response gene to mesoderm induction in X. laevis ${ }^{179}$, and it is upstream of the planar cell polarity pathway (PCP) and dorsal convergence and extension (CE). ${ }^{180,}{ }^{181}$ Its expression in the notochord indicates the onset of CE in the $X$. laevis mid-gastrula. ${ }^{182}$ Convergence and extension movements lead to vertebrate body elongation. ${ }^{163,183}$

In gastrulae of E. machalilla, Epipedobates anthonyi, and G. riobambae, brachyury was detected in a superficial ring around the blastopore. Brachyury deep expression in the likely prospective mesoderm was detected after blastopore closure, followed by expression in the elongating notochord. These expression patterns may relate to the function of brachyury in blastopore formation, prospective mesoderm development, and body elongation by CE. Brachyury expression in the prospective mesoderm and notochord of $G$. riobambae and $E$. machalilla was delayed in comparison with $X$ laevis. ${ }^{104,184,185}$ Superficial expression of brachyury is unknown for $X$. laevis.

\section{Conserved gastrulation features}

The dorsal blastopore lip and external morphology-Frog and urodele embryos develop a dorsal blastopore lip that shares organizer properties ${ }^{186,187}$ and has conserved expression of the organizer gene $\operatorname{Lhx} 1 .^{79}, 168,171,172$ The blastopore lip closes around a yolk plug in most frogs and urodeles. Exceptions include the giant salamander Megalobatrachus maximus and the frog Rhacophorus, where the ventral blastopore lip never forms or its formation is significantly delayed. ${ }^{188}$ 
Another exception is the embryonic disk of small cells that develops around the closing blastopore in the large embryos of the marsupial frog, G. riobambae (Figure 1a). ${ }^{42,104,} 189$ The embryonic disk is reviewed later. Patterns of gastrulation, however, do not associate strictly with egg size, as the large eggs of E. coqui develop an equatorial blastopore lip and do not form an embryonic disk. ${ }^{190}$

Involution and blastopore formation-Involution at the blastopore lip is conserved as demonstrated by vital dye staining. ${ }^{42,191,192}$ Lhx 1 expression around the blastopore is required for involution movements in $X$. laevis embryos. ${ }^{171,172,176}$ By comparison, expression of Lhx1 around the blastopore is an indication of involution in embryos of túngara frogs, E. machalilla, and G. riobambae. ${ }^{79,168}$

Vegetal contraction-Contraction at the vegetal pole is a morphogenetic movement of frog and urodele embryos. ${ }^{189,193}$ The vegetal surface of the $G$. riobambae gastrula undergoes $50 \%$ contraction, reducing vegetal surface. This movement is associated with bottle-like cells in the vegetal region, and with formation of a pit at the vegetal pole. ${ }^{104,189}$ Contraction pushes the vegetal mass inside the embryo, likely contributing to endoderm internalization and vegetal rotation.

Brachet's cleft-Separation of endomesoderm from ectoderm occurs at Brachet's cleft. ${ }^{182,194}$ Brachet's cleft was detected in E. machalilla and G. riobambae gastrulae, indicating separation between neuroectoderm from endomesoderm in embryos of these frogs. ${ }^{104}$ Further analysis is required to determine whether tissue separation at Brachet's cleft is controlled by non-canonical Wnt signaling, as in X. laevis. ${ }^{195,196}$

\section{Variable gastrulation features}

The transparent blastocoel roof-The blastocoel roof is a pigmented epithelium that consists of several cell layers in amphibians with small and aquatic eggs. The blastocoel roof becomes thinner during gastrulation, due to the movements of epiboly. ${ }^{197,}{ }^{198}$ In X. laevis, a change in cell shape of the outer layer and radial intercalation from the inner cell layers contribute to thinning and expansion of the blastocoel roof, as it surrounds the whole embryo. ${ }^{197}$ Despite this thinning, the blastocoel roof epithelium remains opaque. In contrast, the blastocoel roof thins to a transparent cell-monolayer in embryos of frogs and urodeles that are derived from large eggs. Amphibians that develop transparent blastocoel roofs include the anurans G. riobambae, E. machalilla, and E. coqui (Figure 6), and the urodeles Andrias japonicus, Cryptobranchus allegheniensis, and E. eschscholtzii. $41,85,189,199,200$ The transparent roof provides a window that allows observation of internal cell movements. This property could be exploited to observe in vivo cell migration during gastrulation.

In $G$. riobambae, an increase in the volume of the blastocoel causes most of the thinning of the blastocoel roof, prior to the epibolic movements of gastrulation. ${ }^{189}$ The blastocoel roof is derived from yolk-poor cells near the animal pole. The monolayered blastocoel epithelium will cover the embryonic disk and the entire yolk mass at later stages ${ }^{189}$ (Figure 6b, c), a morphology that resembles blastoderm thinning and spreading, due to epiboly, to enclose the entire yolk cell of zebrafish embryos. ${ }^{183}$

Similarly, in E. coqui, most of the single-celled blastocoel roof ends up as an epithelium covering the large mass of yolky cells. ${ }^{201}$ This epithelium undergoes apoptosis, and is replaced by the body wall. The blastocoel roof of these embryos is more like an extraembryonic tissue, whose function is to encase the large mass of yolk-rich cells. Accordingly, it is not surprising that the pluripotency of the blastocoel roof differs from $X$. laevis. Cells of the $X$. laevis blastocoel roof are pluripotent and can be induced to follow 
many developmental pathways in animal cap experiments. The pluripotency of the animal cap is true for the urodele, $A$. mexicanum, as well. ${ }^{202,203}$ Unlike $X$. laevis and $A$. mexicanum, the $E$. coqui animal cap does not respond to inducing signals in tissue recombinants. ${ }^{158}$ Pluripotency does not seem to be the case for the blastocoel roof of either G. riobambae or E. coqui.

Presumptive mesoderm and mesoderm induction-The Nodal gene family plays the most important role in mesendoderm induction in vertebrates, with one Nodal family member in chick, mouse and axolotl, three different Nodal genes in zebrafish and six in Xenopus. ${ }^{203,204}$ Diversification of the Nodal gene family during the course of evolution allowed division of labor. For example, in $X$. laevis, different nodal genes play sequential roles in mesendoderm induction and gastrulation movements in contrast with the one-gene situation of mammals and axolotl. ${ }^{203,204}$ Swiers et al. ${ }^{203}$ propose that mesoderm specification by a single nodal gene is the vertebrate ancestral state, as it is conserved between urodeles and mammals.

In the axolotl, nodal activates $m i x$, an endodermal transcription factor. Mix, in turn, is necessary for brachyury expression for mesoderm. This sequential regulation contrasts with the situation in $X$. laevis, where nodal signaling activates both mix and brachyury, and they are mutually inhibitory. ${ }^{203}$

The nature of mesoderm inducing signals in large frog embryos is unknown. In blastula and early gastrula of E. coqui, mesoderm inducing activity is present only in superficial, equatorial cells (Figure 5). The large vegetal cells lack this activity. ${ }^{157,158}$

In the frogs E. randi, E. machalilla and $G$. riobambae, mesoderm induction may coincide in time with $X$. laevis, according to lhx 1 expression in the likely prospective mesoderm. ${ }^{168,171,172,176}$ In contrast, brachyury expression in the prospective mesoderm is delayed until blastopore closure in E. machalilla and $G$. riobambae, frogs that delay CE and notochord elongation until after blastopore closure. ${ }^{104,184,185}$ We conclude that retardation of body elongation in these frogs associates with the retarded expression of brachyury in the prospective mesoderm.

Surface vs. deep mesoderm-In $X$. laevis, most of the presumptive mesoderm is located internally in the blastula. ${ }^{188,192}$ In contrast, the amount of presumptive mesoderm found on the embryonic surface varies greatly among anurans, and the presumptive mesoderm is located on the surface of the blastula in urodeles. ${ }^{192}$ Internalization of the urodele surface mesoderm occurs during gastrulation and neurulation through subduction, a specialized form of ingression that involves apical constriction of cells. ${ }^{188,192}$ As cells become internalized, subduction guides closure of the blastopore, and this process occurs through a bilateral primitive streak. This mechanism differs from $X$. laevis and surprisingly resembles ingression through the single primitive streak of chick and mammalian embryos. ${ }^{192}$

Organizer variation-The organizer of amphibian embryos develops from the dorsal blastopore lip, and according to inductive properties, it is divided into head, trunk, and tail organizers. The head and trunk organizers are represented by the prechordal plate and notochord, respectively. ${ }^{186,187,205}$ Head and trunk organizers are separable as indicated by transplantation of early and late blastopore lip in urodele and $X$. laevis embryos. The early lip induced only head structures, and the late lip induced only the tail. ${ }^{186,187,205}$ Lhx 1 expression revealed the simultaneous presence of both organizers in the $X$. laevis and túngara frog mid-gastrula. ${ }^{168,175}$ In contrast, natural separation of head and trunk organizers 
was observed in embryos of E. machalilla. The head organizer develops during gastrulation, and the trunk organizer was detected after blastopore closure (Figure 7). ${ }^{168}$

Movement of the prechordal plate away from the blastopore and towards the animal pole in $E$. machalilla may occur by the highly conserved pattern of active migration of mesendodermal cells onto the extracellular matrix of the blastocoel roof as in X. laevis and other vertebrates. ${ }^{163,188,206}$ In contrast, the trunk mesoderm remains in the thickened circumblastoral collar (CBC) of E. machalilla embryos until the end of gastrulation, when $\mathrm{CE}$ allows elongation of the notochord and dorsal tissues (Figure 7).

Elongation of the archenteron and notochord-Archenteron elongation in amphibian embryos results from a combination of epiboly, vegetal rotation and CE. ${ }^{207}$ The archenteron elongates starting in mid-gastrula in $X$. laevis, E. coqui, and túngara frog embryos. ${ }^{75,79,104}$ In contrast, archenteron elongation is delayed until the end of gastrulation in E. machalilla, and G. riobambae. ${ }^{79}, 104$

Elongation of the notochord in vertebrates is guided by the non-canonical Wnt/PCP and CE. ${ }^{183}$ The notochord starts to elongate in the mid-gastrula of $X$. laevis and túngara frog embryos. ${ }^{75,79,104}$ In contrast, notochord elongation occurs after blastopore closure in $E$. machalilla, $G$. riobambae, and E. coqui as detected by brachyury and lhx 1 expression. $75,158,184,185$

A possible explanation for the divergent pattern of notochord elongation derives from differences in the onset of CE. An early expression of brachyury is required to activate the non-canonical Wnt/PCP and CE in the $X$. laevis mid-gastrula 180,181, leading to accelerated body elongation. In contrast, brachyury expression in the presumptive mesoderm and CE are delayed until the end of gastrulation in E. machalilla (Figure 7), G. riobambae and E. coqui embryos $79,104,158$, allowing for delayed elongation of the trunk.

Separation of convergence and extension from gastrulation-In $X$. laevis, cells that involute during gastrulation move away from the blastopore lip along the elongating archenteron. This pattern is due to active cell migration of head mesoderm and to CE movements of trunk mesoderm. ${ }^{163,188,208,209}$ Once the blastopore closes, the CBC is small. Dorsal CE is the major force for blastopore closure on the $X$. laevis dorsal side. ${ }^{210,211}$ It may also be the leading force for closing the blastopore in túngara frog embryos, as suggested by elongation of the notochord in the mid-gastrula and similar gastrula morphology. 75,79

The $X$. laevis ventral blastopore lip undergoes convergence and thickening (CT), and this movement may guide blastopore closure in the ventral side. ${ }^{188}$ Thickening of the ventral blastopore lip results from convergence in absence of extension, and cells of presumptive mesoderm are maintained in the blastopore lip for later addition to the dorsal axis. ${ }^{188,212}$

In embryos of $E$. machalilla and $G$. riobambae, involuted cells remain for the most part in the blastopore lip, as only the prechordal plate migrates anteriorly during gastrulation (Figure 1a). Consequently, the blastopore lip thickens, and forms a large CBC (Figure 1b). ${ }^{79,104}$ This morphology apparently results from a major role of CT during gastrulation and retardation of CE until blastopore closure. The comparison suggests that in slow developing frogs, CT and other forces may close the blastopore in absence of CE.

Gastrulation and CE are naturally separated in G. riobambae, and E. machalilla, and can be separated experimentally in $X$. laevis and zebrafish embryos. Dorsal development of $X$. laevis embryos is inhibited by ultraviolet irradiation in the vegetal region of the fertilized 
egg or by injection of suramin into the blastocoel. ${ }^{213,214}$ Similarly, $X$. laevis embryos deficient for dishevelled ( $d v 12$ ), a component of the PCP, do not undergo CE or elongate the notochord, and the blastopore lip thickens. ${ }^{207}$ In zebrafish, Wnt/PCP mutants go through normal epiboly and internalization without disturbing cell fates. The resultant embryos have shortened anterior-posterior body axis and wider dorsal structures like the notochord and somites. ${ }^{183}$ The thick blastopore lip of ventralized $X$. laevis embryos and shortened body axis of these zebrafish mutants resemble gastrulae of $G$. riobambae, and $E$. machalilla. Tada and $\mathrm{Kai}^{196}$ propose that there is separation of CE from gastrulation in axial and non-axial tissues of zebrafish and mouse embryos, processes that occur simultaneously in $X$. laevis. Therefore, it is not surprising that in the evolution of several frogs, CE movements have been moved to post-gastrula stages, delaying elongation of the body. The comparison additionally indicates that gastrulation is modular, as previously proposed. ${ }^{104,207}$

The embryonic disk of Gastrotheca riobambae-At the onset of gastrulation, embryos of $G$. riobambae develop a blastoporal-rim at the vegetal border of the one-cell epithelium that covers the blastocoel and cleaved yolk. The blastoporal-rim is a uniform circumferential structure that consists of several tiers of surface elongated cells around the future yolk plug. ${ }^{104}$ Later, bottle cells are detected in the likely dorsal side of the blastoporal-rim, and a small dorsal blastopore lip develops. ${ }^{104}$ Dorsal lip formation is followed by bottle cell formation and involution all around. The blastopore lip becomes thick with involuted cells, and the archenteron is very small. Bottle cells are found at the anterior tip of the archenteron as in $X$. laevis embryos. ${ }^{189}$ Embryos of $X$. laevis or $E$. machalilla do not develop a circumferentially symmetric blastoporal rim. Instead, circumferentially elongated cells appear gradually first in dorsal side and then in lateral and ventral regions of the involuting marginal zone prior to blastopore lip development. ${ }^{104,215}$ Cell involution around the blastopore lip of $G$. riobambae resembles internalization around the entire circumference of the blastoderm margin in zebrafish embryos. ${ }^{183}$

The thick blastopore lip constitutes the embryonic disk at blastopore closure (Figure 1a, b). On the surface the embryonic disk consists of small cells (Figure 1c). ${ }^{42}$ Underneath, the $\mathrm{CBC}$ is large, and the tiny archenteron is slightly larger on the dorsal side (Figure 1b). ${ }^{104}$ When the archenteron elongates along with the notochord, due to $\mathrm{CE}$, the margin of the archenteron expands anisotropically. This expansion results in the displacement of the CBC in the embryonic disk from a medial to a posterior location, resembling the displacement of Hensen's node in chick and mouse embryos. ${ }^{42,104}$ In spite of the similar development of a large $\mathrm{CBC}$ and retardation of $\mathrm{CE}$ and notochord elongation, an embryonic disk was not detected in embryos of E. machalilla. ${ }^{104}$ Formation of an embryonic disk in embryos of $G$. riobambae uses the same forces that shape the gastrula of $X$. laevis, and provide an extreme example of gastrulation modularity.

\section{ADVANCED DEVELOPMENT IN E. coqui}

Omission of the tadpole stages in $E$. coqui is associated with numerous changes in embryos. For example the tail has been modified into a vascularized and membranous structure that allows gas exchanges during embryonic development (Figure 3c). Precocious development of the limbs and head and other changes associated with this reproductive mode are reviewed in this section.

\section{Limb development}

Direct developing anuran embryos all develop on top of a large yolk mass, which is surrounded after gastrulation by epidermis and lateral plate mesoderm as in embryos of frogs with tadpoles. Large limb buds form early, and the development of the limbs is continuous through embryogenesis (Figure 3). In some species, the forelimb is covered by 
the operculum as in tadpoles, but in E. coqui, the operculum never completely covers the forelimb. ${ }^{216}$ Tadpoles all initiate limbs late, and limb development is slow until metamorphosis. Since the different direct developers were derived independently from ancestors with tadpoles, the inhibition of limb development in tadpoles must be relatively easy to modify in evolutionary time. That suggests that only a small number of genes or molecular and cellular interactions suppress limb development in tadpoles.

Limb development in $E$. coqui has been described in some detail. ${ }^{201,217-221}$ In general, limb developmental characters are conserved with chicken, mouse, zebrafish, and other animals. These characters include shh expression ${ }^{219}$, a retinoic acid requirement for forelimb initiation $^{222,223}$, and the migration of $1 b x 1$ expressing cells to form limb muscle. ${ }^{224}$ Unlike chicken or mouse, E. coqui limb buds lack an apical ectodermal ridge (AER). ${ }^{218}$ This is likely a lack of the morphological structure only, since expression of distal-less at the distal tip suggests the presence of an AER. ${ }^{219,225}$

\section{Head development}

A second feature of direct developing anuran embryos is a froglike head with big eyes and a gaping jaw (Figure 3). In E. coqui, cells in both the retina and the corresponding optic tectum proliferate rapidly and continuously from eye initiation, contributing to the relative prominence of the eye in the head. ${ }^{226,227}$ This early proliferation contrasts with eyes in tadpoles, where rapid proliferation is delayed until after feeding begins.

With respect to jaws, those of tadpoles and frogs are radically different. Tadpoles have extra cartilages, the suprarostral and the infrarostral, to support their mouths with the keratinous beak and teeth. The lower jaw of tadpoles contains a large palatoquadrate cartilage, which joins the skull at an acute angle, and a short Meckel's cartilage. At metamorphosis, the suprarostral and infrarostral cartilages are lost, and Meckel's cartilage elongates. The elongation of Meckel's cartilage shifts the palatoquadrate posteriorly, so that it now joins the skull at a slightly obtuse angle. ${ }^{228}$

Development of jaws in E. coqui has been investigated at multiple levels by Hanken and coworkers, including immunocytochemistry for collagen and muscle, in situs for skeletal regulatory molecules and collagen, and stains for cartilage and bone. ${ }^{229-231}$ The palatoquadrate and Meckel's cartilages are in a mid-metamorphic position, when they are first detectable. ${ }^{229}$ Tadpole-specific muscles do not appear, and adult muscles first form in a mid-metamorphic position. ${ }^{230}$ There is no trace of the suprarostral cartilage, although early anterior expression of bmp4, sox 9 , and runx 2 suggests a potential cartilaginous domain, whose differentiation is not realized. ${ }^{231}$ These results show that most of the tadpole-specific jaw structures have been cleared from the derived ontogeny of $E$. coqui.

Jaw cartilages develop from cranial neural crest cells, raising the question as to whether evolution of the E. coqui jaws has involved neural crest changes. Tracing populations of cranial neural crest cells by both morphological and molecular markers has not revealed substantive differences between cranial neural crest in $E$. coqui and species with tadpoles. ${ }^{225,232,233}$ A more critical test would be transplantation of cranial neural crest between embryos of $E$. coqui and those of a tadpole species, as has been done for quail and chick beaks. 234

As might be expected from the number of independent origins of direct development, there is variation in the degree to which tadpole-specific structures have been eliminated.

Elimination of the tadpole is very complete in Eleutherodactylus. In contrast, the embryo of the direct developer, Philautus silus, retains both suprarostral and infrarostral cartilages and the tadpole orientation of the lower jaw cartilages. ${ }^{235}$ 


\section{Thyroid hormone in direct development}

Thyroid hormone causes metamorphosis of the tadpole to the frog, which raises the question as to whether thyroid hormone plays a role in a direct developer. Indeed it does. Inhibition of thyroid hormone synthesis by methimazole blocks many developmental changes in $E$. coqui, including transformation of the skin, growth of muscles, resorption of the tail, and differentiation of the stomach and intestinal lining. ${ }^{236,237}$

In addition to the inhibition by methimazole, there are other indicators that $E$. coqui utilizes thyroid hormone. The thyroid gland is differentiated when the embryo in its jelly capsule is about two weeks old ${ }^{238}$, and the gene for thyroid hormone receptor, thrb, is expressed. ${ }^{236}$ $T h r b$ is upregulated by thyroid hormone in E. coqui ${ }^{237}$, as it is in X. laevis metamorphosis. ${ }^{239,240}$ Its expression is a molecular indicator of thyroid hormone activity in these embryos.

An open question is whether thyroid hormone plays a role in the early development of limbs, jaws, eyes, and other structures of the early E. coqui embryo, before the thyroid gland has developed and before upregulation of thrb. Maternal levels of both thra and thrb RNAs are high in E. coqui. ${ }^{236}$ Thyroid hormone receptor RNA and protein are also present in $X$. laevis oocytes ${ }^{240-243}$, and thyroid hormone is detected in eggs of anurans, fish, and birds. $^{244-250}$ These results suggest that thyroid hormone signaling occurs prior to development of the embryo's thyroid gland. This signaling could play important roles in early development not only of E. coqui but also of other animals. The best way to test whether maternal thyroid hormone and its receptors are important in early development would be to use a specific inhibitor of the receptors. Unfortunately, such an inhibitor is not presently available, despite its obvious utility in treatment of hyperthyroidism.

\section{Nutritional endoderm}

A feature of E. coqui direct development is the presence of a novel tissue called nutritional endoderm. ${ }^{251}$ Nutritional endoderm is a mass of cells, filled with yolk platelets, attached to the developing intestine (Figure 3f). Once the yolk is used, the cells disappear and do not contribute to any frog tissues. The nutritional endoderm is derived from the vegetal region of the blastula (Figure 5). As discussed earlier, this region differs from the vegetal region of a $X$. laevis blastula in that it lacks both vegt RNA as well as mesoderm inducing activity. The nutritional endoderm cells are likely not exposed to signals that cause the development of definitive endoderm.

A further characteristic of the nutritional endoderm is that utilization of its yolk depends on thyroid hormone. ${ }^{237} \mathrm{Thr} b$ is expressed in the nutritional endoderm, and methimazole blocks yolk utilization. The effect of thyroid hormone is late, so much of the yolk in the nutritional endoderm is used only after the froglet has hatched from its jelly capsule. Whether nutritional endoderm and its thyroid hormone dependency exist in any other amphibian is not known. There are many lineages of both direct developing frogs as well as species with non-feeding, nidicolus tadpoles that have a large mass of yolk-filled cells. These species could easily be examined for thyroid dependency of late yolk utilization by treating them with methimazole. It is possible that even in $X$. laevis and other species with feeding tadpoles, a careful mapping of endodermal cell fate would detect nutritional endodermal cells. ${ }^{251}$

\section{Conclusion}

A major difficulty in the analysis of embryonic development in less studied amphibians is obtaining embryos. In some cases, it may be easy to collect embryos from nature, whereas in other cases such as caecilians, this represents a major drawback. Frogs, for which handling 
and reproduction are known such as Dendrobatids and several species of foam-nesting frogs of the genus Engystomops, represent promising species for further analysis. Dendrobatid frogs are particularly interesting since several species are available in pet shops worldwide. Similarly, the African frog Hyperolius is a favorite pet, whose early development is known only in its basic aspects. ${ }^{146}$

Besides amphibians available through the pet trade, zoos, or amateur herpetologists, any amphibian that breeds in an urban environment in tropical or sub-tropical regions such as $E$. coqui, would be a candidate for laboratory use. Urban amphibians are relatively insensitive to noise and disrupted light cycles, so they are likely to breed freely in laboratories. The reason for the tropical and sub-tropical stipulation is the greatest diversity of reproductive adaptations occurs in those regions.

There are so many adaptations waiting to be analyzed now that we have an important base line for developmental comparison in the frog $X$. laevis, and other intensively studied organisms. It is important and interesting to make use of the natural experiments of amphibian diversity to understand better the fundamental features of development.

\section{Acknowledgments}

We thank former and current members of the del Pino and Elinson laboratories. In particular we acknowledge I. Alarcón and I. Moya for their help with images of $G$. riobambae gastrulae and S. Hardesty for Figure 6. RPE was supported by grant 1R15HD059070-01 from NIH and grant IOS-0841720 from NSF. EMdP was supported by grants from the Pontificia Universidad Católica del Ecuador, and a grant 07-017 LDC/BIO/LA-UNESCO FR 3240144821 from The Academy of Sciences for the Developing World (TWAS).

\section{LITERATURE CITED}

1. Holtfreter, J.; Hamburger, V. Amphibians. In: Willier, BH.; Weiss, PA.; Hamburger, V., editors. Analysis of development. W. B. Saunders Company; Philadelphia: 1955. p. 230-296.

2. Gurdon JB, Hopwood N. The introduction of Xenopus laevis into developmental biology: of empire, pregnancy testing and ribosomal genes. Int J Dev Biol. 2000; 44:43-50. [PubMed: 10761846]

3. Callery EM. There's more than one frog in the pond: a survey of the Amphibia and their contributions to developmental biology. Semin Cell Dev Biol. 2006; 17:80-92. [PubMed: 16337414]

4. Beetschen JC. How did urodele embryos come into prominence as a model system? Int J Dev Biol. 1996; 40:629-636. [PubMed: 8877434]

5. Malacinski GM, Rufus R. Humphrey (1892-1977). American Zoologist. 1978; 18:191-193.

6. Smith JJ, Putta S, Zhu W, Pao GM, Verma IM, Hunter T, Bryant SV, Gardiner DM, Harkins TT, Voss SR. Genic regions of a large salamander genome contain long introns and novel genes. BMC Genomics. 2009; 10:19. [PubMed: 19144141]

7. Elinson RP. Fertilization in amphibians: the ancestry of the block to polyspermy. Int Rev Cytol. 1986; 101:59-100. [PubMed: 3516916]

8. Iwao, Y. Fertilization in amphibians. In: Tarin, JJ.; Cano, A., editors. Fertilization in protozoa and metazoan animals, cellular and molecular aspects. Springer-Verlag; Berlin: 2000. p. 147-191.

9. Nieuwkoop, PD.; Sutasurya, LA. Primordial germ cells in the chordates. Cambridge University Press; Cambridge: 1979.

10. Johnson AD, Crother B, White ME, Patient R, Bachvarova RF, Drum M, Masi T. Regulative germ cell specification in axolotl embryos: a primitive trait conserved in the mammalian lineage. Philos Trans R Soc Lond B Biol Sci. 2003; 358:1371-1379. [PubMed: 14511484]

11. Johnson AD, Drum M, Bachvarova RF, Masi T, White ME, Crother BI. Evolution of predetermined germ cells in vertebrate embryos: implications for macroevolution. Evol Dev. 2003; 5:414-431. [PubMed: 12823457]

Wiley Interdiscip Rev Dev Biol. Author manuscript; available in PMC 2013 May 01. 
12. Johnson AD, Richardson E, Bachvarova RF, Crother BI. Evolution of the germ line-soma relationship in vertebrate embryos. Reproduction. 2011; 141:291-300. [PubMed: 21228047]

13. Rose, CS. Hormonal control of larval development and evolution - Amphibians. In: Hall, BK.; Wake, MH., editors. The origin and evolution of larval forms. Academic Press; San Diego: 1999. p. 167-216.

14. Stocum DL, Cameron JA. Looking proximally and distally: 100 years of limb regeneration and beyond. Dev Dyn. 2011; 240:943-968. [PubMed: 21290477]

15. Duellman, WE.; Trueb, L. Biology of amphibians. McGraw-Hill; New York: 1986.

16. Thibaudeau, G.; Altig, R. Endotrophic anurans, development and evolution. In: McDiarmid, RW.; Altig, R., editors. Tadpoles, the biology of anuran larvae. University of Chicago Press; Chicago: 1999. p. 170-188.

17. Cannatella, DC.; Vieites, DR.; Zhang, P.; Wake, MH.; Wake, DB. Amphibians (Lissamphibia). In: Hedges, SB.; Kumar, S., editors. The timetree of life. Oxford University Press; 2009. p. 353-356.

18. Bossuyt, F.; Roelants, K. Frogs and toads (Anura). In: Hedges, SB.; Kumar, S., editors. The timetree of life. Oxford University Press; 2009. p. 357-364.

19. Wake, MH. A brief history of research on gymnophionan reproductive biology and development. In: Exbrayat, J-M., editor. Reproductive Biology and Phylogeny of Gymnophionans. Science Publishers; Enfield, N. H.: 2006. p. 1-37.

20. Dunker N, Wake MH, Olson WM. Embryonic and larval development in the caecilian Ichthyophis kohtaoensis (Amphibia, gymnophiona): a staging table. J Morphol. 2000; 243:3-34. [PubMed: 10629095]

21. Woltering JM, Vonk FJ, Muller H, Bardine N, Tuduce IL, de Bakker MA, Knochel W, Sirbu IO, Durston AJ, Richardson MK. Axial patterning in snakes and caecilians: evidence for an alternative interpretation of the Hox code. Dev Biol. 2009; 332:82-89. [PubMed: 19409887]

22. Kohlsdorf T, Cummings MP, Lynch VJ, Stopper GF, Takahashi K, Wagner GP. A molecular footprint of limb loss: sequence variation of the autopodial identity gene Hoxa-13. J Mol Evol. 2008; 67:581-593. [PubMed: 18855040]

23. Mannaert A, Amemiya CT, Bossuyt F. Comparative analyses of vertebrate posterior HoxD clusters reveal atypical cluster architecture in the caecilian Typhlonectes natans. BMC Genomics. 2010; 11:658. [PubMed: 21106068]

24. Kleinteich T. Ontogenetic differences in the feeding biomechanics of oviparous and viviparous caecilians (Lissamphibia: Gymnophiona). Zoology (Jena). 2010; 113:283-294. [PubMed: 20952171]

25. Kupfer A, Muller H, Antoniazzi MM, Jared C, Greven H, Nussbaum RA, Wilkinson M. Parental investment by skin feeding in a caecilian amphibian. Nature. 2006; 440:926-929. [PubMed: 16612382]

26. Wilkinson M, Kupfer A, Marques-Porto R, Jeffkins H, Antoniazzi MM, Jared C. One hundred million years of skin feeding? Extended parental care in a Neotropical caecilian (Amphibia: Gymnophiona). Biol Lett. 2008; 4:358-361. [PubMed: 18547909]

27. Hanken, J. Larvae in amphibian development and evolution. In: Hall, BK.; Wake, MH., editors. The origin and evolution of larval forms. Academic Press; San Diego: 1999. p. 61-108.

28. Nieuwkoop PD. What are the key advantages and disadvantages of urodele species compared to anurans as a model system for experimental analysis of early development? Int J Dev Biol. 1996; 40:617-619. [PubMed: 8877432]

29. Page RB, Boley MA, Smith JJ, Putta S, Voss SR. Microarray analysis of a salamander hopeful monster reveals transcriptional signatures of paedomorphic brain development. BMC Evol Biol. 2010; 10:199. [PubMed: 20584293]

30. Page RB, Monaghan JR, Walker JA, Voss SR. A model of transcriptional and morphological changes during thyroid hormone-induced metamorphosis of the axolotl. Gen Comp Endocrinol. 2009; 162:219-232. [PubMed: 19275901]

31. Huggins P, Johnson CK, Schoergendorfer A, Putta S, Bathke AC, Stromberg AJ, Voss SR. Identification of differentially expressed thyroid hormone responsive genes from the brain of the Mexican Axolotl (Ambystoma mexicanum). Comp Biochem Physiol C Toxicol Pharmacol. 2011 
32. Sprules WG. Environmental factors and the incidence of neoteny in Ambystoma gracile (Baird) (Amphibia: Caudata). Can J Zool. 1974; 52:1545-1552. [PubMed: 4442000]

33. Doyle JM, Whiteman HH. Paedomorphosis in Ambystoma talpoideum: effects of initial body size variation and density. Oecologia. 2008; 156:87-94. [PubMed: 18274781]

34. Voss SR, Shaffer HB. What insights into the developmental traits of urodeles does the study of interspecific hybrids provide? Int J Dev Biol. 1996; 40:885-893. [PubMed: 8877462]

35. Malacinski GM. The Mexican axolotl, Ambystoma mexicanum: its biology and developmental genetics, and its autonomous cell-lethal genes. American Zoologist. 1978; 18:195-206.

36. Safi R, Vlaeminck-Guillem V, Duffraisse M, Seugnet I, Plateroti M, Margotat A, DuterqueCoquillaud M, Crespi EJ, Denver RJ, Demeneix B, et al. Pedomorphosis revisited: thyroid hormone receptors are functional in Necturus maculosus. Evol Dev. 2006; 8:284-292. [PubMed: 16686639]

37. Vlaeminck-Guillem V, Safi R, Guillem P, Leteurtre E, Duterque-Coquillaud M, Laudet V. Thyroid hormone receptor expression in the obligatory paedomorphic salamander Necturus maculosus. Int J Dev Biol. 2006; 50:553-560. [PubMed: 16741870]

38. Wassersug RJ. The adaptive significance of the tadpole stage with comments on the maintenance of complex life cycles in anurans. American Zoologist. 1975; 15:405-417.

39. Rot-Nikcevic I, Wassersug RJ. Arrested development in Xenopus laevis tadpoles: how size constrains metamorphosis. J Exp Biol. 2004; 207:2133-2145. [PubMed: 15143146]

40. Wake DB, Hanken J. Direct development in the lungless salamanders: what are the consequences for developmental biology, evolution and phylogenesis? Int J Dev Biol. 1996; 40:859-869. [PubMed: 8877460]

41. Collazo A, Keller R. Early development of Ensatina eschscholtzii: an amphibian with a large, yolky egg. Evodevo. 2010; 1:6. [PubMed: 20849648]

42. del Pino EM, Elinson RP. Gastrulation produces an embryonic disc, a novel developmental pattern for frogs. Nature. 1983; 306:589-591.

43. Chippindale PT, Bonett RM, Baldwin AS, Wiens JJ. Phylogenetic evidence for a major reversal of life-history evolution in plethodontid salamanders. Evolution. 2004; 58:2809-2822. [PubMed: 15696758]

44. Altig, R.; McDiarmid, RW., editors. Tadpoles, the biology of anuran larvae. University of Chicago Press; Chicago: 1999.

45. Haas A, Hertwig S, Das I. Extreme tadpoles: the morphology of the fossorial megophryid larva, Leptobrachella mjobergi. Zoology (Jena). 2006; 109:26-42. [PubMed: 16376062]

46. Handrigan GR, Haas A, Wassersug RJ. Bony-tailed tadpoles: the development of supernumerary caudal vertebrae in larval megophryids (Anura). Evol Dev. 2007; 9:190-202. [PubMed: 17371401]

47. Handrigan GR, Wassersug RJ. The metamorphic fate of supernumerary caudal vertebrae in South Asian litter frogs (Anura: Megophryidae). J Anat. 2007; 211:271-279. [PubMed: 17559539]

48. Mohanty-Hejmadi P, Dutta SK, Mahapatra P. Limbs generated at site of tail amputation in marbled balloon frog after vitamin A treatment. Nature. 1992; 355:352-353. [PubMed: 1731249]

49. Maden M, Corcoran J. Role of thyroid hormone and retinoid receptors in the homeotic transformation of tails into limbs in frogs. Dev Genet. 1996; 19:85-93. [PubMed: 8792612]

50. Handrigan GR, Wassersug RJ. The anuran Bauplan: a review of the adaptive, developmental, and genetic underpinnings of frog and tadpole morphology. Biol Rev Camb Philos Soc. 2007; 82:1-25. [PubMed: 17313522]

51. Ruibal R, Thomas E. The obligate carnivorous larvae of the frog, Lepidobatrachus laevis (Leptodactylidae). Copeia. 1988; 1988:591-604.

52. Carroll EJ Jr. Seneviratne AM, Ruibal R. Gastric pepsin in an anuran larva. Dev Growth Differ. 1991; 33:499-507.

53. Pfennig D. The adaptive significance of an environmentally-cued developmental switch in an anuran tadpole. Oecologia. 1990; 85:101-107.

54. Pfennig DW, Murphy PJ. Character displacement in polyphenic tadpoles. Evolution. 2000; 54:1738-1749. [PubMed: 11108600] 
55. Storz BL, Travis J. Temporally dissociated, trait-specific modifications underlie phenotypic polyphenism in Spea multiplicata tadpoles, which suggests modularity. ScientificWorldJournal. 2007; 7:715-726. [PubMed: 17619754]

56. Storz BL, Moerland TS. Spadefoot-tadpole polyphenism: Histological analysis of differential muscle growth in carnivores and omnivores. J Morphol. 2009; 270:1262-1268. [PubMed: 19459191]

57. Ledon-Rettig CC, Pfennig DW, Crespi EJ. Diet and hormonal manipulation reveal cryptic genetic variation: implications for the evolution of novel feeding strategies. Proc Biol Sci. 2010; 277:3569-3578. [PubMed: 20573627]

58. Ledon-Rettig CC, Pfennig DW, Nascone-Yoder N. Ancestral variation and the potential for genetic accommodation in larval amphibians: implications for the evolution of novel feeding strategies. Evol Dev. 2008; 10:316-325. [PubMed: 18460093]

59. Lannoo MJ, Bachmann MD. Aspects of cannibalistic morphs in a population of Ambystomat. tigrinum larvae. American Midland Naturalist. 1984; 112:103-109.

60. Michimae H, Wakahara M. A tadpole-induced polyphenism in the salamander Hynobius retardatus. Evolution. 2002; 56:2029-2038. [PubMed: 12449490]

61. Michimae H, Wakahara M. Variation in cannibalistic polyphenism between populations in the salamander Hynobius retardatus. Zoolog Sci. 2002; 19:703-707. [PubMed: 12130800]

62. Collins JP, Cheek JE. Effect of food and density on development of typical and cannibalistic salamander larvae in Ambystoma tigrinum nebulosum. American Zoologist. 1983; 23:77-84.

63. Pfennig DW, Collins JP. Kinship affects morphogenesis in cannibalistic salamanders. Nature. 1993; 362:836-838. [PubMed: 8479520]

64. Michimae H, Nishimura K, Wakahara M. Mechanical vibrations from tadpoles' flapping tails transform salamander's carnivorous morphology. Biol Lett. 2005; 1:75-77. [PubMed: 17148132]

65. Michimae H, Nishimura K, Tamori Y, Wakahara M. Maternal effects on phenotypic plasticity in larvae of the salamander Hynobius retardatus. Oecologia. 2009; 160:601-608. [PubMed: 19352721]

66. Altig R, Johnston GF. Guilds of anuran larvae: relationships among developmental modes, morphologies, and habitats. Herpetological Monographs. 1989; 3:81-109.

67. Vera Candioti MF, Ubeda C, Lavilla EO. Morphology and metamorphosis of Eupsophus calcaratus tadpoles (Anura: Leptodactylidae). J Morphol. 2005; 264:161-177. [PubMed: 15761818]

68. Crump ML. Life history consequences of feeding versus non-feeding in a facultatively non-feeding toad larva. Oecologia. 1989; 78:486-489.

69. Ron SR, Santos JC, Cannatella DC. Phylogeny of the tungara frog genus Engystomops (= Physalaemus pustulosus species group; Anura: Leptodactylidae). Mol Phylogenet Evol. 2006; 39:392-403. [PubMed: 16446105]

70. Ryan, MJ. The Túngara frog: a study in sexual selection and communication. The University of Chicago Press; Chicago: 1985.

71. Ryan MJ, Rand AS. Sexual selection in female perceptual space: how female tungara frogs perceive and respond to complex population variation in acoustic mating signals. Evolution. 2003; 57:2608-2618. [PubMed: 14686535]

72. Mackenzie CD, Smith BO, Meister A, Blume A, Zhao X, Lu JR, Kennedy MW, Cooper A. Ranaspumin-2: structure and function of a surfactant protein from the foam nests of a tropical frog. Biophys J. 2009; 96:4984-4992. [PubMed: 19527658]

73. Davidson EH, Hough BR. Synchronous oogenesis in Engystomops pustulosus, a neotropic anuran suitable for laboratory studies: localization in the embryo of RNA synthesized at the lampbrush stage. J Exp Zool. 1969; 172:25-48. [PubMed: 5372000]

74. Dalgetty L, Kennedy MW. Building a home from foam--tungara frog foam nest architecture and three-phase construction process. Biol Lett. 2010; 6:293-296. [PubMed: 20106853]

75. Romero-Carvajal A, Saenz-Ponce N, Venegas-Ferrin M, Almeida-Reinoso D, Lee C, Bond J, Ryan MJ, Wallingford JB, del Pino EM. Embryogenesis and laboratory maintenance of the foam-nesting tungara frogs, genus Engystomops (= Physalaemus). Dev Dyn. 2009; 238:1444-1454. [PubMed: 19384855] 
76. Hough BR, Yancey PH, Davidson EH. Persistence of maternal RNA in Engystomops embryos. J Exp Zool. 1973; 185:357-368. [PubMed: 4748953]

77. Radice GP, Neff AW, Shim YH, Brustis JJ, Malacinski GM. Developmental histories in amphibian myogenesis. Int J Dev Biol. 1989; 33:325-343. [PubMed: 2702121]

78. Gatherer D, del Pino EM. Somitogenesis in the marsupial frog Gastrotheca riobambae. Int J Dev Biol. 1992; 36:283-291. [PubMed: 1525016]

79. del Pino EM, Venegas-Ferrín M, Romero-Carvajal A, Montenegro-Larrea P, Sáenz-Ponce N, Moya IM, Alarcón I, Sudou N, Yamamoto S, Taira M. A comparative analysis of frog early development. Proc Natl Acad Sci U S A. 2007; 104:11882-11888. [PubMed: 17606898]

80. Afonin B, Ho M, Gustin JK, Meloty-Kapella C, Domingo CR. Cell behaviors associated with somite segmentation and rotation in Xenopus laevis. Dev Dyn. 2006; 235:3268-3279. [PubMed: 17048252]

81. Nieuwkoop, PD.; Faber, J. Normal Table of Xenopus laevis (Daudin). Garland Publishing; New York: 1994.

82. Hausen, P.; Riebesell, M. The early development of Xenopus laevis. Springer; Berlin: 1991.

83. Pollister AW, Moore JA. Tables for the normal development of Rana sylvatica. Anatomical Record. 1937; 68:489-496.

84. del Pino EM, Escobar B. Embryonic stages of Gastrotheca riobambae (Fowler) during maternal incubation and comparison of development with that of other egg-brooding hylid frogs. J Morphol. 1981; 167:277-295. [PubMed: 7241600]

85. Del Pino EM, Avila ME, Pérez OD, Benítez MS, Alarcón I, Noboa V, Moya IM. Development of the dendrobatid frog Colostethus machalilla. Int J Dev Biol. 2004; 48:663-670. [PubMed: 15470639]

86. Grant T, Frost DR, Caldwell JP, Gagliardo R, Haddad CFB, Kok PJR, Means DB, Noonan BP, Schargel WE, Wheeler WC. Phylogenetic systematics of dart-poison frogs and their relatives (Amphibia: Athesphatanura: Dendrobatidae). Bulletin American Museum Natural History. 2006; 299:1-262.

87. Daly JW. Thirty years of discovering arthropod alkaloids in amphibian skin. J Nat Prod. 1998; 61:162-172. [PubMed: 9461669]

88. Daly JW. The chemistry of poisons in amphibian skin. Proc Natl Acad Sci U S A. 1995; 92:9-13. [PubMed: 7816854]

89. Daly JW, Garraffo HM, Spande TF, Decker MW, Sullivan JP, Williams M. Alkaloids from frog skin: the discovery of epibatidine and the potential for developing novel non-opioid analgesics. Nat Prod Rep. 2000; 17:131-135. [PubMed: 10821107]

90. Coloma, LA. Ecuadorian frogs of the genus Colostethus (Anura:Dendrobatidae). Natural History Museum, University of Kansas; Lawrence, Kan.: 1995.

91. Wiens JJ, Kuczynski CA, Duellman WE, Reeder TW. Loss and re-evolution of complex life cycles in marsupial frogs: does ancestral trait reconstruction mislead? Evolution. 2007; 61:1886-1899. [PubMed: 17683431]

92. Duellman WE, Maness SJ. The reproductive behavior of some hylid marsupial frogs. Journal of Herpetology. 1980; 14:213-222.

93. Wassersug RJ, Duellman WE. Oral structures and their development in egg-brooding hylid frog embryos and larvae: evolutionary and ecological implications. Journal of Morphology. 1984; 182:1-37.

94. Trueb L. Systematic relationships of neotropical horned frogs, genus Hemiphractus (Anura, Hylidae). Occasional Papers Museum of Natural History University of Kansas. 1974; 29:1-60.

95. Jones RE, Gerrard AM, Roth JJ. Estrogen and brood pouch formation in the marsupial frog, Gastrotheca riobambae. J Exp Zool. 1973; 184:177-184. [PubMed: 4704215]

96. del Pino EM. Morphology of the pouch and incubatory integument in marsupial frogs (Hylidae). Copeia. 1980; 1980:10-17.

97. del Pino EM. Progesterone induces incubatory changes in the brooding pouch of the frog Gastrotheca riobambae (Fowler). J Exp Zool. 1983; 227:159-163. [PubMed: 6619764] 
98. del Pino EM, Sanchez G. Ovarian structure of the marsupial frog Gastrotheca riobambae (Fowler). J Morphol. 1977; 153:153-161. [PubMed: 894718]

99. del Pino EM. Modifications of oogenesis and development in marsupial frogs. Development. 1989; 107:169-187. [PubMed: 2698797]

100. delPino EM, Galarza ML, de Albuja CM, Humphries AA. The maternal pouch and development in the marsupial frog Gastrotheca riobambae (Fowler). Biological Bulletin. 1975; 149:480-491.

101. Greven H, Richter S. Morphology of skin incubation in Pipa carvalhoi (Anura: Pipidae). J Morphol. 2009; 270:1311-1319. [PubMed: 19434720]

102. del Pino EM, Loor-Vela S. The pattern of early cleavage of the marsupial frog Gastrotheca riobambae. Development. 1990; 110:781-789. [PubMed: 2088720]

103. del Pino EM, Medina A. Neural development in the marsupial frog Gastrotheca riobambae. Int J Dev Biol. 1998; 42:723-731. [PubMed: 9712527]

104. Moya IM, Alarcón I, del Pino EM. Gastrulation of Gastrotheca riobambae in comparison with other frogs. Dev Biol. 2007; 304:467-478. [PubMed: 17306246]

105. Alcocer I, Santacruz X, Steinbeisser H, Thierauch KH, del Pino EM. Ureotelism as the prevailing mode of nitrogen excretion in larvae of the marsupial frog Gastrotheca riobambae (Fowler) (Anura, Hylidae). Comp Biochem Physiol Comp Physiol. 1992; 101:229-231. [PubMed: 1348458]

106. del Pino EM, Alcocer I, Grunz H. Urea is necessary for the culture of embryos of the marsupial frog Gastrotheca riobambae, and is tolerated by embryos of the aquatic frog Xenopus laevis. Dev Growth Differ. 1994; 36:73-80.

107. Elinson RP, del Pino EM, Townsend DS, Cuesta FC, Eichhorn P. A practical guide to the developmental biology of terrestrial-breeding frogs. Biological Bulletin. 1990; 179:163-177.

108. Wake, MH. Phylogenesis of direct development and viviparity in vertebrates. In: Wake, DB.; Roth, G., editors. Complex organismal functions: integration and evolution in vertebrates. John Wiley \& Sons; Chichester: 1989. p. 235-250.

109. Callery EM, Fang H, Elinson RP. Frogs without polliwogs: evolution of anuran direct development. Bioessays. 2001; 23:233-241. [PubMed: 11223880]

110. Elinson RP. Direct development: an alternative way to make a frog. Genesis. 2001; 29:91-95. [PubMed: 11170349]

111. Lamotte M, Lescure J. Tendances adaptives a l'affranchissement du milieu aquatique chez les amphibiens anoures. Terre at la Vie. 1977; 31:225-311.

112. Townsend DS, Stewart MM. Direct development in Eleutherodactylus coqui (Anura: Leptodactylidae): a staging table. Copeia. 1985; 1985:423-436.

113. Meegaskumbura M, Bossuyt F, Pethiyagoda R, Manamendra-Arachchi K, Bahir M, Milinkovitch MC, Schneider CJ. Sri Lanka: an amphibian hot spot. Science. 2002; 298:379. [PubMed: 12376694]

114. Bahir MM, Meegaskumbura M, Manamendra-Arachchi K, Schneider CJ, Pethiyagoda R. Reproduction and terrestrial direct development in Sri Lankan shrub frogs (Ranidae: Rhacophorinae: Philautus). Raffles Bulletin of Zoology. 2005; (Supplement 12):339-350.

115. Anstis M. Direct development in the Australian myobatrachid frog Metacrinia nichollsi from Western Australia. Records of the Western Australian Museum. 2008; 24:133-150.

116. Anstis M, Roberts JD, Altig R. Direct development in two Myobatrachid frogs, Arenophryne rotunda Tyler and Myobatrachus gouldii Gray, from Western Australia. Records of the Western Australian Museum. 2007; 23:259-271.

117. Hedges SB, Duellman WE, Heinicke MP. New World direct-developing frogs (Anura:Terrarana): Molecular phylogeny, classification, biogeography, and conservation. Zootaxa. 2008; 1737:1182.

118. Heinicke MP, Duellman WE, Hedges SB. Major Caribbean and Central American frog faunas originated by ancient oceanic dispersal. Proc Natl Acad Sci U S A. 2007; 104:10092-10097. [PubMed: 17548823]

119. Schmid M, Steinlein C, Bogart JP, Feichtinger W, Leon P, La Marca E, Diaz LM, Sanz A, Chen $\mathrm{SH}$, Hedges SB. The chromosomes of terraranan frogs. Insights into vertebrate cytogenetics. Cytogenet Genome Res. 2010; 130-131:1-568. [PubMed: 21063086] 
120. Elinson RP. Fertilization and aqueous development of the Puerto Rican terrestrial-breeding frog, Eleutheroductylus coqui. J Morphol. 1987; 193:217-224.

121. Matova N, Cooley L. Comparative aspects of animal oogenesis. Dev Biol. 2001; 231:291-320. [PubMed: 11237461]

122. Spradling AC. Germline cysts: communes that work. Cell. 1993; 72:649-651. [PubMed: 8453660]

123. Cooley L. Oogenesis: variations on a theme. Dev Genet. 1995; 16:1-5. [PubMed: 7758241]

124. King, RC.; Büning, J. The origin and functioning of insect oocytes and nurse cells. In: Kerkut, GA., editor. Comprehensive insect physiology, biochemistry and pharmacology: Embryogenesis and reproduction. Vol. 1. Pergamon Press; New York: 1985. p. 37-82.

125. Bastock R, St Johnston D. Drosophila oogenesis. Curr Biol. 2008; 18:R1082-1087. [PubMed: 19081037]

126. del Pino EM, Humphries AA. Multinucleate oogenesis in Flectonotus pygmaeus and other marsupial frogs. Biological Bulletin. 1978; 154:198-212.

127. Gall JG, Wu Z, Murphy C, Gao H. Structure in the amphibian germinal vesicle. Exp Cell Res. 2004; 296:28-34. [PubMed: 15120990]

128. Handwerger KE, Gall JG. Subnuclear organelles: new insights into form and function. Trends Cell Biol. 2006; 16:19-26. [PubMed: 16325406]

129. Nizami Z, Deryusheva S, Gall JG. The Cajal body and histone locus body. Cold Spring Harb Perspect Biol. 2010; 2:a000653. [PubMed: 20504965]

130. Dawid IB, Sargent TD. Xenopus laevis in developmental and molecular biology. Science. 1988; 240:1443-1448. [PubMed: 3287620]

131. Pepling ME, de Cuevas M, Spradling AC. Germline cysts: a conserved phase of germ cell development? Trends Cell Biol. 1999; 9:257-262. [PubMed: 10370240]

132. Macgregor HC, Kezer J. Gene amplification in oocytes with 8 germinal vesicles from the tailed frog Ascaphus truei Stejneger. Chromosoma. 1970; 29:189-206. [PubMed: 5461075]

133. del Pino EM, Steinbeisser H, Hofmann A, Dreyer C, Campos M, Trendelenburg MF. Oogenesis in the egg-brooding frog Gastrotheca riobambae produces large oocytes with fewer nucleoli and low RNA content in comparison to Xenopus laevis. Differentiation. 1986; 32:24-33.

134. del Pino EM, Murphy C, Masson PH, Gall JG. 5S rRNA-encoding genes of the marsupial frog Gastrotheca riobambae. Gene. 1992; 111:235-238. [PubMed: 1541401]

135. Macgregor HC, del Pino EM. Ribosomal gene amplification in multinucleate oocytes of the egg brooding hylid frog Flectonotus pygmaeus. Chromosoma. 1982; 85:475-488. [PubMed: 6181943]

136. Wallace RA, Misulovin Z. Long-term growth and differentiation of Xenopus oocytes in a defined medium. Proc Natl Acad Sci U S A. 1978; 75:5534-5538. [PubMed: 281702]

137. Wallace RA, Misulovin Z, Etkin LD. Full-grown oocytes from Xenopus laevis resume growth when placed in culture. Proc Natl Acad Sci U S A. 1981; 78:3078-3082. [PubMed: 16593019]

138. Kobel HR, Egens De Sasso M, Zlotowski C. Developmental capacity of aneuploid Xenopus species hybrids. Differentiation. 1979; 14:51-58. [PubMed: 478210]

139. Berger L. Systematics and hybridization in European green frogs of the Rana esculenta complex. Journal of Herpetology. 1973; 7:1-10.

140. Uzzell T, Berger L, Gunther R. Diploid and triploid progeny from a diploid female of Rana esculenta (Amphibia Salientia). Proceedings of the Academy of Natural Sciences of Philadelphia. 1975; 127:81-91.

141. Uzzell T, Holz H, Berger L. Genome exclusion in gametogenesis by an interspecific Rana hybrid: evidence from electrophoresis of individual oocytes. Journal of Experimental Zoology. 1980; 214:251-259.

142. Tunner HG, Heppich S. Premeiotic genome exclusion during oogenesis in the common edible frog, Rana esculenta. Naturwissenschaften. 1981; 68:207-208. [PubMed: 6974310]

143. Lee C, Le MP, Cannatella D, Wallingford JB. Changes in localization and expression levels of Shroom 2 and spectrin contribute to variation in amphibian egg pigmentation patterns. Dev Genes Evol. 2009; 219:319-330. [PubMed: 19554350] 
144. Elinson RP, Rowning B. A transient array of parallel microtubules in frog eggs: potential tracks for a cytoplasmic rotation that specifies the dorso-ventral axis. Dev Biol. 1988; 128:185-197. [PubMed: 3289985]

145. Elinson RP, Ninomiya H. Parallel microtubules and other conserved elements of dorsal axial specification in the direct developing frog, Eleutherodactylus coqui. Dev Genes Evol. 2003; 213:28-34. [PubMed: 12590350]

146. Chipman AD, Haas A, Khaner O. Variations in anuran embryogenesis: yolk-rich embryos of Hyperolius puncticulatus (Hyperoliidae). Evol Dev. 1999; 1:49-61. [PubMed: 11324020]

147. Elinson, RP. Egg evolution. In: Wake, DB.; Roth, G., editors. Complex organismal functions: integration and evolution in vertebrates. John Wiley \& Sons; Chichester: 1987. p. 251-262.

148. Elinson RP. Nutritional endoderm: a way to breach the holoblastic-meroblastic barrier in tetrapods. J Exp Zool B Mol Dev Evol. 2009; 312:526-532. [PubMed: 18473365]

149. Signoret J, Lefresne J. Contribution a l'etude de la segmentation de l'oeuf d'axolotl. I. Definition de la transition blastuleenne. Ann Embryol Morph. 1971; 2:451-459.

150. Brown HA. Developmental anatomy of the tailed frog (Ascaphus truei): a primitive frog with large eggs and slow development. Journal of Zoology, London. 1989; 217:525-537.

151. Smith BG. Preliminary report on the embryology of Cryptobranchus allegheniensis. Biological Bulletin. 1906; 11:146-165.

152. Ecleshymer AC, Wilson JM. Normal plates of the development of Necturus maculosus. 1910; 11

153. Collazo A, Marks SB. Development of Gyrinophilus porphyriticus: Identification of the anncestral developmental pattern in the salamander family Plethodontidae. Journal of Experimental Zoology. 1994; 268:239-258.

154. Nath K, Boorech JL, Beckham YM, Burns MM, Elinson RP. Status of RNAs, localized in Xenopus laevis oocytes, in the frogs Rana pipiens and Eleutherodactylus coqui. J Exp Zool B Mol Dev Evol. 2005; 304:28-39. [PubMed: 15515051]

155. Blackler AW. Embryonic sex cells in amphibia. Advances in Reproductive Physiology. 1966; 1:9-28.

156. Beckham YM, Nath K, Elinson RP. Localization of RNAs in oocytes of Eleutherodactylus coqui, a direct developing frog, differs from Xenopus laevis. Evol Dev. 2003; 5:562-571. [PubMed: 14984038]

157. Elinson RP, Beckham Y. Development in frogs with large eggs and the origin of amniotes. Zoology (Jena). 2002; 105:105-117. [PubMed: 16351861]

158. Ninomiya H, Zhang Q, Elinson RP. Mesoderm formation in Eleutherodactylus coqui: body patterning in a frog with a large egg. Dev Biol. 2001; 236:109-123. [PubMed: 11456448]

159. Sutasurya LA, Nieuwkoop PD. The induction of the primoridial germ cells in the urodeles. Wilhelm Roux' Archiv. 1974; 175:199-220.

160. Johnson AD, Bachvarova RF, Drum M, Masi T. Expression of axolotl DAZL RNA, a marker of germ plasm: widespread maternal RNA and onset of expression in germ cells approaching the gonad. Dev Biol. 2001; 234:402-415. [PubMed: 11397009]

161. Bachvarova RF, Masi T, Drum M, Parker N, Mason K, Patient R, Johnson AD. Gene expression in the axolotl germ line: Axdazl, Axvh, Axoct-4, and Axkit. Dev Dyn. 2004; 231:871-880. [PubMed: 15517581]

162. Nath K, Elinson RP. RNA of AmVegT, the axolotl orthologue of the Xenopus meso-endodermal determinant, is not localized in the oocyte. Gene Expr Patterns. 2007; 7:197-201. [PubMed: 16920404]

163. Solnica-Krezel L. Conserved patterns of cell movements during vertebrate gastrulation. Curr Biol. 2005; 15:R213-228. [PubMed: 15797016]

164. Dawid IB, Breen JJ, Toyama R. LIM domains: multiple roles as adapters and functional modifiers in protein interactions. Trends Genet. 1998; 14:156-162. [PubMed: 9594664]

165. Hobert O, Westphal H. Functions of LIM-homeobox genes. Trends Genet. 2000; 16:75-83. [PubMed: 10652534] 
166. Karavanov AA, Saint-Jeannet JP, Karavanova I, Taira M, Dawid IB. The LIM homeodomain protein Lim-1 is widely expressed in neural, neural crest and mesoderm derivatives in vertebrate development. Int J Dev Biol. 1996; 40:453-461. [PubMed: 8793615]

167. Yasuoka Y, Kobayashi M, Kurokawa D, Akasaka K, Saiga H, Taira M. Evolutionary origins of blastoporal expression and organizer activity of the vertebrate gastrula organizer gene $1 \mathrm{hx} 1$ and its ancient metazoan paralog $1 h x 3$. Development. 2009; 136:2005-2014. [PubMed: 19439497]

168. Venegas-Ferrin M, Sudou N, Taira M, del Pino EM. Comparison of Lim1 expression in embryos of frogs with different modes of reproduction. Int J Dev Biol. 2010; 54:195-202. [PubMed: 19876816]

169. Yamamoto S, Hikasa H, Ono H, Taira M. Molecular link in the sequential induction of the Spemann organizer: direct activation of the cerberus gene by Xlim-1, Xotx2, Mix.1, and Siamois, immediately downstream from Nodal and Wnt signaling. Dev Biol. 2003; 257:190-204. [PubMed: 12710967]

170. Srivastava M, Larroux C, Lu DR, Mohanty K, Chapman J, Degnan BM, Rokhsar DS. Early evolution of the LIM homeobox gene family. BMC Biol. 2010; 8:4. [PubMed: 20082688]

171. Taira M, Jamrich M, Good PJ, Dawid IB. The LIM domain-containing homeo box gene Xlim-1 is expressed specifically in the organizer region of Xenopus gastrula embryos. Genes Dev. 1992; 6:356-366. [PubMed: 1347750]

172. Taira M, Otani H, Jamrich M, Dawid IB. Expression of the LIM class homeobox gene Xlim-1 in pronephros and CNS cell lineages of Xenopus embryos is affected by retinoic acid and exogastrulation. Development. 1994; 120:1525-1536. [PubMed: 7914163]

173. Taira M, Otani H, Saint-Jeannet JP, Dawid IB. Role of the LIM class homeodomain protein Xlim-1 in neural and muscle induction by the Spemann organizer in Xenopus. Nature. 1994; 372:677-679. [PubMed: 7990959]

174. Dressler GR. Advances in early kidney specification, development and patterning. Development. 2009; 136:3863-3874. [PubMed: 19906853]

175. Taira M, Saint-Jeannet JP, Dawid IB. Role of the Xlim-1 and Xbra genes in anteroposterior patterning of neural tissue by the head and trunk organizer. Proc Natl Acad Sci U S A. 1997; 94:895-900. [PubMed: 9023353]

176. Hukriede NA, Tsang TE, Habas R, Khoo PL, Steiner K, Weeks DL, Tam PP, Dawid IB. Conserved requirement of Lim1 function for cell movements during gastrulation. Dev Cell. 2003; 4:83-94. [PubMed: 12530965]

177. Technau U. Brachyury, the blastopore and the evolution of the mesoderm. Bioessays. 2001; 23:788-794. [PubMed: 11536291]

178. Marcellini S, Technau U, Smith JC, Lemaire P. Evolution of Brachyury proteins: identification of a novel regulatory domain conserved within Bilateria. Dev Biol. 2003; 260:352-361. [PubMed: 12921737]

179. Smith JC, Price BM, Green JB, Weigel D, Herrmann BG. Expression of a Xenopus homolog of Brachyury $(\mathrm{T})$ is an immediate-early response to mesoderm induction. Cell. 1991; 67:79-87. [PubMed: 1717160]

180. Conlon FL, Smith JC. Interference with brachyury function inhibits convergent extension, causes apoptosis, and reveals separate requirements in the FGF and activin signalling pathways. Dev Biol. 1999; 213:85-100. [PubMed: 10452848]

181. Tada M, Smith JC. Xwnt11 is a target of Xenopus Brachyury: regulation of gastrulation movements via Dishevelled, but not through the canonical Wnt pathway. Development. 2000; 127:2227-2238. [PubMed: 10769246]

182. Winklbauer R, Schurfeld M. Vegetal rotation, a new gastrulation movement involved in the internalization of the mesoderm and endoderm in Xenopus. Development. 1999; 126:3703-3713. [PubMed: 10409515]

183. Roszko I, Sawada A, Solnica-Krezel L. Regulation of convergence and extension movements during vertebrate gastrulation by the Wnt/PCP pathway. Semin Cell Dev Biol. 2009; 20:986997. [PubMed: 19761865]

184. del Pino EM. The expression of Brachyury (T) during gastrulation in the marsupial frog Gastrotheca riobambae. Dev Biol. 1996; 177:64-72. [PubMed: 8660877] 
185. Benitez MS, del Pino EM. Expression of Brachyury during development of the dendrobatid frog Colostethus machalilla. Dev Dyn. 2002; 225:592-596. [PubMed: 12454936]

186. Niehrs C. Regionally specific induction by the Spemann-Mangold organizer. Nat Rev Genet. 2004; 5:425-434. [PubMed: 15153995]

187. De Robertis EM. Spemann's organizer and self-regulation in amphibian embryos. Nat Rev Mol Cell Biol. 2006; 7:296-302. [PubMed: 16482093]

188. Keller, R.; Shook, D. Gastrulation in amphibians. In: Stern, CD., editor. Gastrulation from cells to embryos. Cold Spring Harbor Laboratory Press; Cold Spring Harbor: 2004. p. 171-203.

189. Elinson RP, del Pino EM. Cleavage and gastrulation in the egg-brooding, marsupial frog, Gastrotheca riobambae. J Embryol Exp Morphol. 1985; 90:223-232. [PubMed: 3834029]

190. delPino, EM.; Elinson, RP. The organizer in amphibians with large eggs: Problems and perspectives. In: Grunz, H., editor. The vertebrate organizer. Springer Verlag; Berlin, Germany: 2003. p. 359-374.

191. Keller RE, Danilchik M, Gimlich R, Shih J. The function and mechanism of convergent extension during gastrulation of Xenopus laevis. J Embryol Exp Morphol. 1985; 89(Suppl):185-209. [PubMed: 3831213]

192. Shook DR, Keller R. Epithelial type, ingression, blastopore architecture and the evolution of chordate mesoderm morphogenesis. J Exp Zool B Mol Dev Evol. 2008; 310:85-110. [PubMed: 18041055]

193. Keller RE. Time-lapse cinematographic analysis of superficial cell behavior during and prior to gastrulation in Xenopus laevis. Journal of Morphology. 1978; 157:223-248.

194. Wacker S, Grimm K, Joos T, Winklbauer R. Development and control of tissue separation at gastrulation in Xenopus. Dev Biol. 2000; 224:428-439. [PubMed: 10926778]

195. Winklbauer R, Medina A, Swain RK, Steinbeisser H. Frizzled-7 signalling controls tissue separation during Xenopus gastrulation. Nature. 2001; 413:856-860. [PubMed: 11677610]

196. Tada M, Kai M. Noncanonical Wnt/PCP signaling during vertebrate gastrulation. Zebrafish. 2009; 6:29-40. [PubMed: 19292674]

197. Keller RE. The cellular basis of epiboly: an SEM study of deep-cell rearrangement during gastrulation in Xenopus laevis. J Embryol Exp Morphol. 1980; 60:201-234. [PubMed: 7310269]

198. Kao KR, Elinson RP. Alteration of the anterior-posterior embryonic axis: the pattern of gastrulation in macrocephalic frog embryos. Dev Biol. 1985; 107:239-251. [PubMed: 4038389]

199. Ishikawa C. Ueber den Riesensalamander Japans. Mitteilungen der deutschen Gesellschaft fur Naturund Volkerkunde Ostaciens. 1908; 11:259-280.

200. Smith BG. The embryology of Cryptobranchus allegheniensis including comparisons with some other vertebrates. II. General embryonic and larval development, with special reference to external features. Journal of Morphology. 1912; 23:455-580.

201. Elinson RP, Fang H. Secondary coverage of the yolk by the body wall in the direct developing frog, Eleutherodactylus coqui: an unusual process for amphibian embryos. Dev Genes Evol. 1998; 208:457-466. [PubMed: 9799426]

202. Nieuwkoop PD. The formation of mesoderm in urodelean amphibians. I. Induction by the endoderm. Wilhelm Roux' Archiv. 1969; 162:341-373.

203. Swiers G, Chen YH, Johnson AD, Loose M. A conserved mechanism for vertebrate mesoderm specification in urodele amphibians and mammals. Dev Biol. 2010; 343:138-152. [PubMed: 20394741]

204. Luxardi G, Marchal L, Thome V, Kodjabachian L. Distinct Xenopus Nodal ligands sequentially induce mesendoderm and control gastrulation movements in parallel to the Wnt/PCP pathway. Development. 2010; 137:417-426. [PubMed: 20056679]

205. Saxen L. Neural induction. Int J Dev Biol. 1989; 33:21-48. [PubMed: 2562048]

206. Winklbauer R, Keller RE. Fibronectin, mesoderm migration, and gastrulation in Xenopus. Dev Biol. 1996; 177:413-426. [PubMed: 8806820]

207. Ewald AJ, Peyrot SM, Tyszka JM, Fraser SE, Wallingford JB. Regional requirements for Dishevelled signaling during Xenopus gastrulation: separable effects on blastopore closure, 
mesendoderm internalization and archenteron formation. Development. 2004; 131:6195-6209. [PubMed: 15548584]

208. Keller RE. Vital dye mapping of the gastrula and neurula of Xenopus laevis. II. Prospective areas and morphogenetic movements of the deep layer. Dev Biol. 1976; 51:118-137. [PubMed: 950072]

209. Keller RE. Vital dye mapping of the gastrula and neurula of Xenopus laevis. I. Prospective areas and morphogenetic movements of the superficial layer. Dev Biol. 1975; 42:222-241. [PubMed: 46836]

210. Keller RE. The cellular basis of amphibian gastrulation. Dev Biol (N Y 1985). 1986; 2:241-327. [PubMed: 3078116]

211. Youn BW, Keller RE, Malacinski GM. An atlas of notochord and somite morphogenesis in several anuran and urodelean amphibians. J Embryol Exp Morphol. 1980; 59:223-247. [PubMed: 6971322]

212. Keller R, Danilchik M. Regional expression, pattern and timing of convergence and extension during gastrulation of Xenopus laevis. Development. 1988; 103:193-209. [PubMed: 3197629]

213. Gerhart J, Danilchik M, Doniach T, Roberts S, Rowning B, Stewart R. Cortical rotation of the Xenopus egg: consequences for the anteroposterior pattern of embryonic dorsal development. Development. 1989; 107(Suppl):37-51. [PubMed: 2699856]

214. Scharf SR, Rowning B, Wu M, Gerhart JC. Hyperdorsoanterior embryos from Xenopus eggs treated with D2O. Dev Biol. 1989; 134:175-188. [PubMed: 2659411]

215. Hardin J, Keller R. The behaviour and function of bottle cells during gastrulation of Xenopus laevis. Development. 1988; 103:211-230. [PubMed: 3197630]

216. Callery EM, Elinson RP. Opercular development and ontogenetic re-organization in a directdeveloping frog. Dev Genes Evol. 2000; 210:377-381. [PubMed: 11180844]

217. Elinson RP. Leg development in a frog without a tadpole (Eleutherodactylus coqui). J Exp Zool. 1994; 270:202-210. [PubMed: 7964555]

218. Richardson MK, Carl TF, Hanken J, Elinson RP, Cope C, Bagley P. Limb development and evolution: a frog embryo with no apical ectodermal ridge (AER). J Anat. 1998; 192(Pt 3):379390. [PubMed: 9688504]

219. Hanken J, Carl TF, Richardson MK, Olsson L, Schlosser G, Osabutey CK, Klymkowsky MW. Limb development in a "nonmodel" vertebrate, the direct-developing frog Eleutherodactylus coqui. J Exp Zool. 2001; 291:375-388. [PubMed: 11754016]

220. Kerney R, Hanken J. Gene expression reveals unique skeletal patterning in the limb of the directdeveloping frog, Eleutherodactylus coqui. Evol Dev. 2008; 10:439-448. [PubMed: 18638321]

221. Schlosser G, Roth G. Evolution of nerve development in frogs. II. Modified development of the peripheral nervous system in the direct-developing frog Eleutherodactylus coqui (Leptodactylidae). Brain Behav Evol. 1997; 50:94-128. [PubMed: 9261555]

222. Lee SY, Elinson RP. Abnormalities of forelimb and pronephros in a direct developing frog suggest a retinoic acid deficiency. Applied Herpetology. 2008; 5:33-46.

223. Elinson RP, Walton Z, Nath K. Raldh expression in embryos of the direct developing frog Eleutherodactylus coqui and the conserved retinoic acid requirement for forelimb initiation. $\mathrm{J}$ Exp Zoolog B Mol Dev Evol. 2008; 310:588-595.

224. Sabo MC, Nath K, Elinson RP. $L b x 1$ expression and frog limb development. Dev Genes Evol. 2009; 219:609-612. [PubMed: 20091319]

225. Fang H, Elinson RP. Patterns of distal-less gene expression and inductive interactions in the head of the direct developing frog Eleutherodactylus coqui. Dev Biol. 1996; 179:160-172. [PubMed: 8873761]

226. Schlosser G, Roth G. Development of the retina is altered in the directly developing frog Eleutherodactylus coqui (Leptodactylidae). Neurosci Lett. 1997; 224:153-156. [PubMed: 9131659]

227. Schlosser G. Development of the retinotectal system in the direct-developing frog Eleutherodactylus coqui in comparison with other anurans. Front Zool. 2008; 5:9. [PubMed: 18573199] 
228. Wassersug, RJ.; Hoff, K. Developmental changes in the orientation of the anuran jaw suspension. A preliminary exploration into the evolution of anuran metamorphosis. In: Hecht, MK.; Wallace, B.; Prance, GT., editors. Evolutionary Biology. Vol. 15. Plenum Publishing; 1982. p. 223-246.

229. Hanken J, Klymkowsky MW, Summers CH, Seufert DW, Ingebrigtsen N. Cranial ontogeny in the direct-developing frog, Eleutherodactylus coqui (Anura: Leptodactylidae), analyzed using wholemount immunohistochemistry. J Morphol. 1992; 211:95-118. [PubMed: 1371162]

230. Hanken J, Klymkowsky MW, Alley KE, Jennings DH. Jaw muscle development as evidence for embryonic repatterning in direct-developing frogs. Proc Biol Sci. 1997; 264:1349-1354. [PubMed: 9332017]

231. Kerney R, Gross JB, Hanken J. Early cranial patterning in the direct-developing frog Eleutherodactylus coqui revealed through gene expression. Evol Dev. 2010; 12:373-382. [PubMed: 20618433]

232. Moury JD, Hanken J. Early cranial neural crest migration in the direct-developing frog, Eleutherodactylus coqui. Acta Anat (Basel). 1995; 153:243-253. [PubMed: 8659248]

233. Olsson L, Moury DJ, Carl TF, Hastad O, Hanken J. Cranial neural crest-cell migration in the direct-developing frog, Eleutherodactylus coqui: molecular heterogeneity within and among migratory streams. Zoology (Jena). 2002; 105:3-13. [PubMed: 16351851]

234. Schneider RA, Helms JA. The cellular and molecular origins of beak morphology. Science. 2003; 299:565-568. [PubMed: 12543976]

235. Kerney R, Meegaskumbura M, Manamendra-Arachchi K, Hanken J. Cranial ontogeny in Philautus silus (Anura: Ranidae: Rhacophorinae) reveals few similarities with other directdeveloping anurans. J Morphol. 2007; 268:715-725. [PubMed: 17538972]

236. Callery EM, Elinson RP. Thyroid hormone-dependent metamorphosis in a direct developing frog. Proc Natl Acad Sci U S A. 2000; 97:2615-2620. [PubMed: 10706622]

237. Singamsetty S, Elinson RP. Novel regulation of yolk utilization by thyroid hormone in embryos of the direct developing frog Eleutherodactylus coqui. Evol Dev. 2010; 12:437-448. [PubMed: 20883213]

238. Jennings DH, Hanken J. Mechanistic basis of life history evolution in anuran amphibians: thyroid gland development in the direct-developing frog, Eleutherodactylus coqui. Gen Comp Endocrinol. 1998; 111:225-232. [PubMed: 9679094]

239. Yaoita Y, Brown DD. A correlation of thyroid hormone receptor gene expression with amphibian metamorphosis. Genes Dev. 1990; 4:1917-1924. [PubMed: 2276625]

240. Eliceiri BP, Brown DD. Quantitation of endogenous thyroid hormone receptors alpha and beta during embryogenesis and metamorphosis in Xenopus laevis. J Biol Chem. 1994; 269:24459_ 24465. [PubMed: 7929109]

241. Kawahara A, Baker BS, Tata JR. Developmental and regional expression of thyroid hormone receptor genes during Xenopus metamorphosis. Development. 1991; 112:933-943. [PubMed: 1935702]

242. Morvan-Dubois G, Demeneix BA, Sachs LM. Xenopus laevis as a model for studying thyroid hormone signalling: from development to metamorphosis. Mol Cell Endocrinol. 2008; 293:7179. [PubMed: 18657589]

243. Duarte-Guterman P, Langlois VS, Pauli BD, Trudeau VL. Expression and T3 regulation of thyroid hormone- and sex steroid-related genes during Silurana (Xenopus) tropicalis early development. Gen Comp Endocrinol. 2010; 166:428-435. [PubMed: 20015451]

244. Prati M, Calvo R, Morreale G, Morreale de Escobar G. L-thyroxine and 3,5,3' -triiodothyronine concentrations in the chicken egg and in the embryo before and after the onset of thyroid function. Endocrinology. 1992; 130:2651-2659. [PubMed: 1572286]

245. Weber GM, Farrar ES, Tom CK, Grau EG. Changes in whole-body thyroxine and triiodothyronine concentrations and total content during early development and metamorphosis of the toad Bufo marinus. Gen Comp Endocrinol. 1994; 94:62-71. [PubMed: 8045369]

246. McNabb FMA, Wilson CM. Thyroid hormone deposition in avian eggs and effects on embryonic development. Integrative and Comparative Biology. 1997; 37:553-560.

247. Flamant F, Samarut J. Involvement of thyroid hormone and its alpha receptor in avian neurulation. Dev Biol. 1998; 197:1-11. [PubMed: 9578614] 
248. Power DM, Llewellyn L, Faustino M, Nowell MA, Bjornsson BT, Einarsdottir IE, Canario AV, Sweeney GE. Thyroid hormones in growth and development of fish. Comp Biochem Physiol C Toxicol Pharmacol. 2001; 130:447-459. [PubMed: 11738632]

249. McComb DM, Gelsleichter J, Manire CA, Brinn R, Brown CL. Comparative thyroid hormone concentration in maternal serum and yolk of the bonnethead shark (Sphyrna tiburo) from two sites along the coast of Florida. Gen Comp Endocrinol. 2005; 144:167-173. [PubMed: 16024019]

250. Ho DH, Reed WL, Burggren WW. Egg yolk environment differentially influences physiological and morphological development of broiler and layer chicken embryos. J Exp Biol. 2011; 214:619-628. [PubMed: 21270311]

251. Buchholz DR, Singamsetty S, Karadge U, Williamson S, Langer CE, Elinson RP. Nutritional endoderm in a direct developing frog: a potential parallel to the evolution of the amniote egg. Dev Dyn. 2007; 236:1259-1272. [PubMed: 17436277]

\section{Further Reading/Resources}

252. del Pino EM. Marsupial Frogs. Sci Am. 1989; 260:110-118.

253. del Pino EM. The early development of Gastrotheca riobambae and Colostethus machalilla, frogs with terrestrial reproductive modes. BiosciEdNet Digital Library Portal for Teaching and Learning in the Biological Sciences. 2010 http://www.apsarchive.org/resource.cfm? submissionID $=3000 \& B E N=1$. 

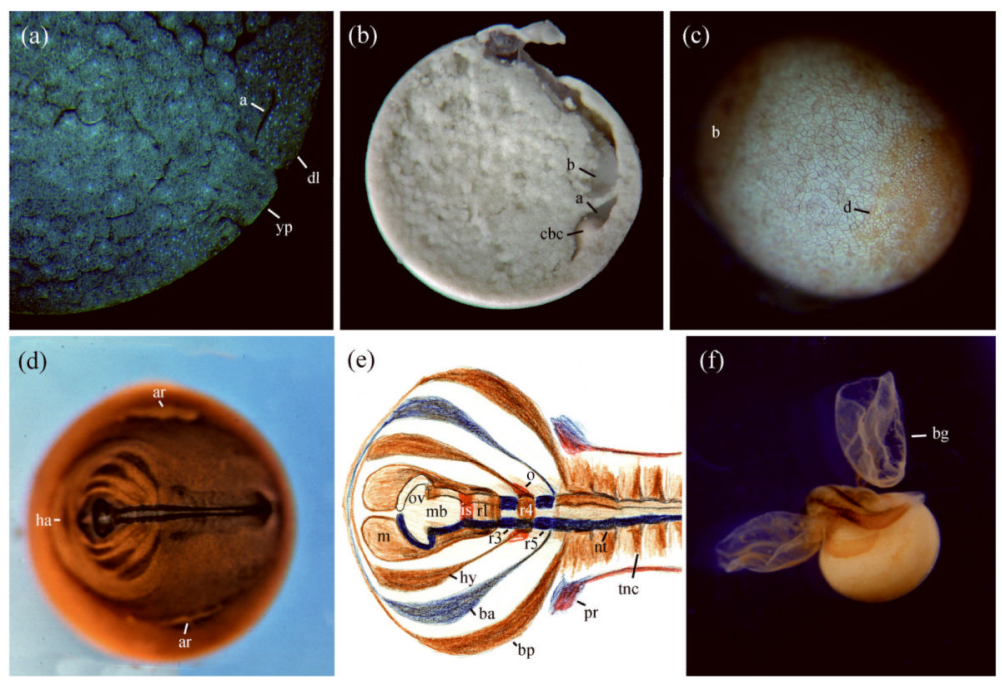

FIGURE 1.

Development of the marsupial frog $G$. riobambae. (A) Sagittal section of a mid gastrula embryo photographed with differential interference contrast and fluorescence to detect cell borders and Hoechst 33258 stained nuclei. Involuted cells remain in the blastopore lip. The small archenteron (a), dorsal blastopore lip (dl), and yolk plug (yp) are present in the subequatorial region. (B) Sagittal bisection of a late gastrula. The archenteron (a) remains small and cells that involuted during gastrulation form a large circumblastoporal collar (cbc) around the closed blastopore. The blastocoel (b) is still visible. This image was reproduced from BiosciEdNet Digital Library Portal for Teaching and Learning in the Biological Sciences 2010 (http://www.apsarchive.org/resource.cfm?submissionID=3000\&BEN=1) (C) The embryonic disk (d) of a late gastrula, stained for cell borders according to del Pino and Elinson. ${ }^{24}$ The body of the embryo is derived from the embryonic disk. The blastocoel (b) is still detectable. (D) Embryo immunostained for a neural antigen with antibody P3. The embryo is flat, and the heart anlage (ha) develops anterior to the head. On the sides of the embryonic disk, there are preparation artifacts (ar). (E) Composite diagram of neural expression, according to del Pino and Medina. ${ }^{84}$ The mandibular (m), hyoid (hy), branchial anterior (ba) and branchial posterior (bp) streams of cranial neural crest, neural crest of the trunk (tnc), optic vesicle (ov), midbrain (mb), isthmus (is), rhombomeres (r), neural tube (nt) and pronephros (pr) were detected by expression of antigen 2G9 (brown), ncam protein (dark blue), epha7 (light blue) and pax2 protein (red). Epha7 expression on r3 and r5 is not shown. (F) Advanced embryo immunostained for myosin. In the living condition the diskshaped bell gills (bg) enveloped the embryo in a vascularized sac. 

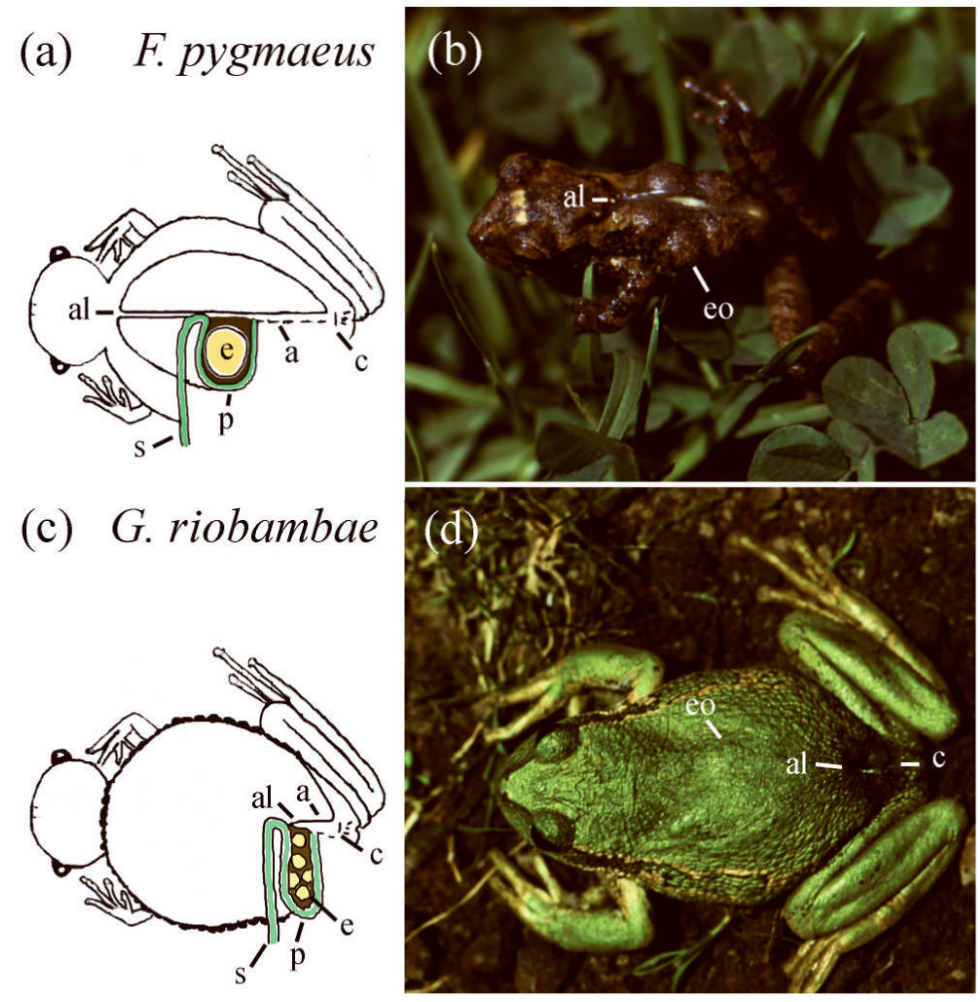

FIGURE 2.

Brooding females of marsupial frogs. (A) Diagram of the pouch and embryos in $F$. pygmaeus. The anterior limit (al) of the pouch aperture (a) is located behind the head, and the posterior limit is above the cloaca (c). This morphology suggests that the pouch developed from foldings of the dorsal skin during evolution. ${ }^{75}$ The pouch lining (p) is continuous with the dorsal skin (s). Embryos (e) are brooded inside the pouch. (B) A brooding female of $F$. pygmaeus. The embryo outlines (eo) are detectable. This small frog, of about $2.5 \mathrm{~cm}$ in snout-vent length, carries 6 embryos, each of $3 \mathrm{~mm}$ in diameter. (C) Diagram of the pouch and embryos in G. riobambae. The anterior limit (al) of the pouch aperture (a) is located near the cloaca (c). The pouch lining (p) is continuous with the dorsal skin (s) as in F. pygmaeus. Embryos (e) are brooded inside the pouch, which occupies the dorsal and lateral sides of the body in a brooding female. (D) A brooding female of $G$.

riobambae. The embryo outlines (eo) are detectable. The pouch opens above the cloaca (c). This frog measures about $5 \mathrm{~cm}$ in snout-vent length and broods about 100 embryos, each of $3 \mathrm{~mm}$ in diameter, for about 4 months. ${ }^{65}$ 

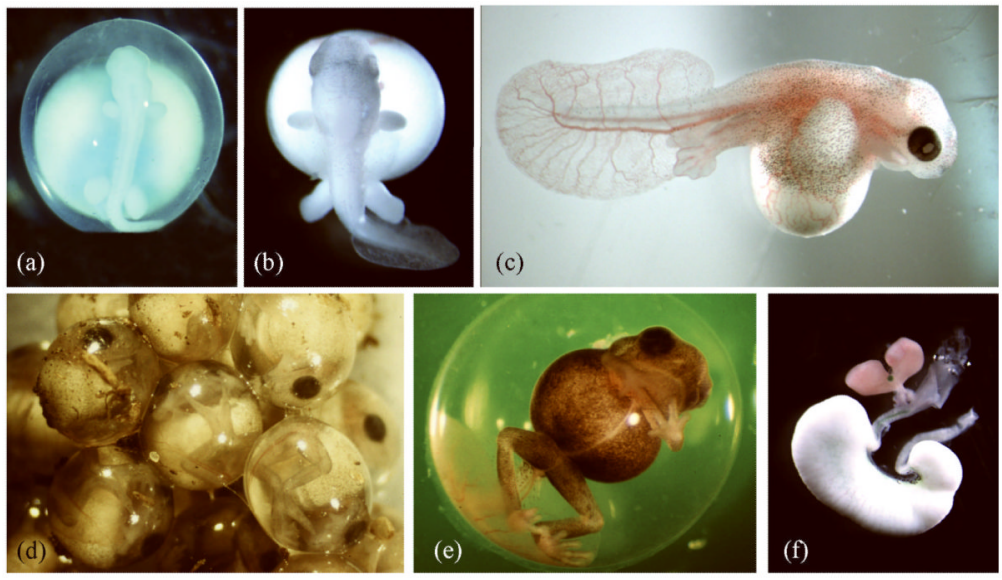

FIGURE 3.

Embryos of the direct developing frog E. coqui. (A) An early E. coqui embryo at TownsendStewart (TS) stage 4/5 has developed limb buds and a broad head. (B) By TS7, foot paddles are evident as well as large froglike eyes. (C) This TS10 embryo has been removed from its jelly capsule. The thin, highly vascularized tail serves as a respiratory surface. The pigmented body wall containing somite-derived musculature is extending over the yolk mass to form a secondary coverage. Digits are present and the eye is darkly pigmented. (D) This picture of a clutch of eggs shows TS12 embryos, as they appear naturally in their jelly capsules. (E) A TS14 froglet is about two days from hatching. (F) A digestive tract, dissected from a newly hatched froglet, shows the yolky cells (white) of the nutritional endoderm, attached to the small intestine. Two lobes of liver (pink) and the gall bladder (green) lie between the stomach and the nutritional endoderm. 

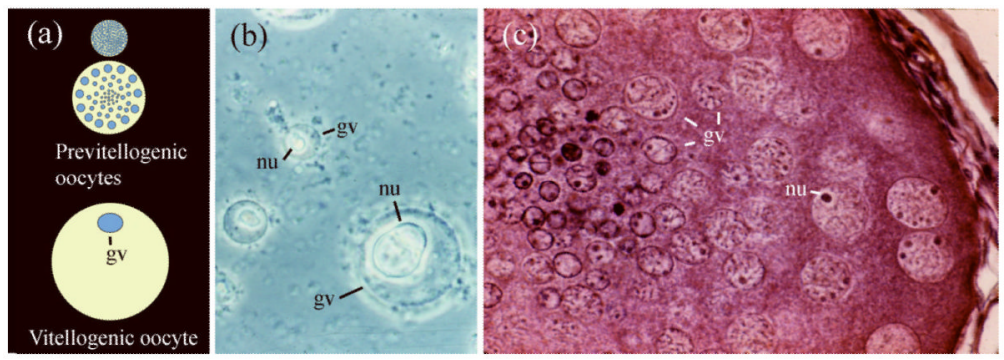

FIGURE 4.

Multinucleate oocytes of $F$. pygmaeus. (A) Diagrams of oocytes. Small oocytes contain about 2000 germinal vesicles of similar diameter, depicted in blue. As oocytes grow, germinal vesicles located toward the periphery enlarge, whereas the centrally located ones remain small. With vitellogenesis, the number of germinal vesicles decreases until only one remains in the full grown oocyte. (B) Germinal vesicles (gv) of different sizes, extruded from a living oocyte. Nucleoli (nu) occur in large and small gvs. (C) Section through a multinucleate oocyte with gvs of various sizes. 

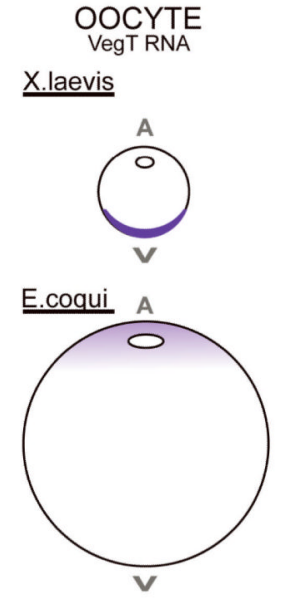

BLASTULA/GASTRULA

Mesoderm Inducing Activity
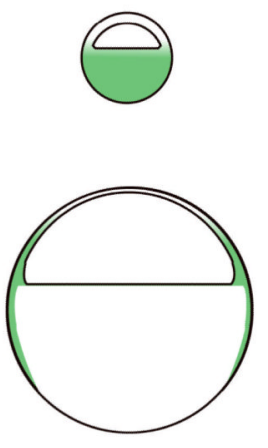

FATE MAP
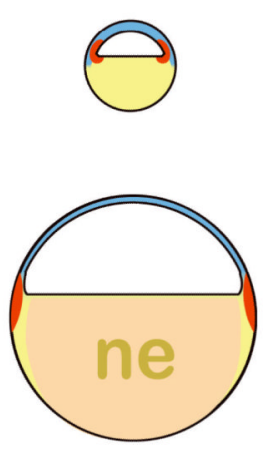

FIGURE 5 .

Pattern of mesendodermal induction in X laevis and E. coqui. All diagrams are sagittal views, drawn to scale. In $X$. laevis, vegt RNA (purple), localized to the oocyte vegetal (V) cortex, leads to nodal signaling (green) in the vegetal half of the blastula/gastrula. This signaling in turn leads to endoderm (yellow) and mesoderm (red) in the fate map. In $E$. coqui, vegt RNA (purple) is near the oocyte animal pole (A) and mesoderm inducing activity (green) is restricted to the peripheral marginal and sub-marginal zones. The absence of vegt activity and nodal signaling is hypothesized to lead to development of nutritional endoderm (ne) (pale orange) in the vegetal core. 

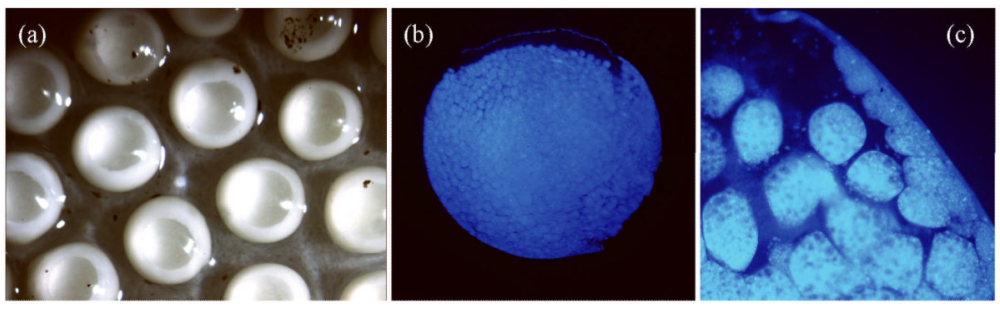

FIGURE 6.

Transparent blastocoel roof. (A) In this animal pole view of E. coqui midgastrulae, the blastocoel roofs are transparent, allowing the interior cavity of the blastocoels to be visible. (B) A section through a G. riobambae late blastula, treated with Hoechst 33258 to stain cell nuclei, reveals the thin blastocoel roof (top) as a single cell thick epithelium. (C) In this enlargement of (B), the thin blastocoel roof extends over large, yolky cells. 


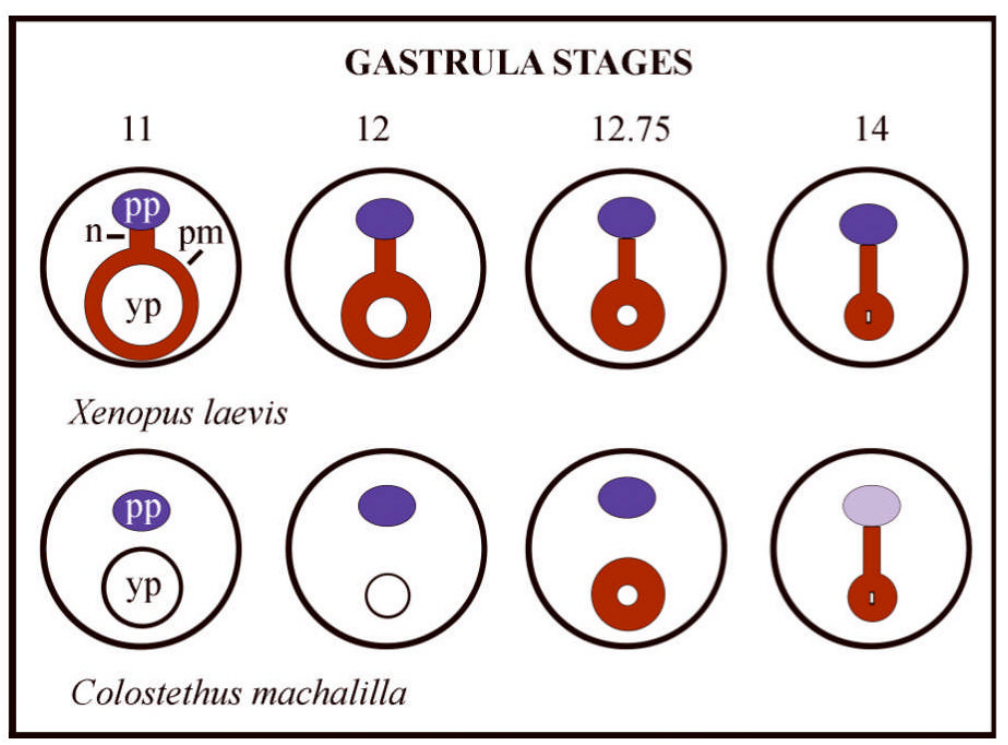

FIGURE 7.

Brachyury and Lhx 1 expression in the gastrula of $X$. laevis and E. machalilla. Brachyury expression in the notochord (n) and presumptive mesoderm (pm) is indicated in red. Lhx1 expression in the prechordal plate is indicated in purple. The yolk plug (yp) is indicated in white. In stage 14 embryos of $E$. machalilla, the pp expression of $\ln x 1$ is downregulated ${ }^{150}$, as indicated in light purple. 